(C2019, Elsevier. Licensed under the Creative Commons Attribution-NonCommercialNoDerivatives 4.0 International http://creativecommons.org/about/downloads 


\title{
Experimental testing of aluminium fumarate MOF for adsorption desalination
}

\author{
Eman Elsayed $^{\mathrm{a}, \mathrm{b}, *}$, Raya AL-Dadaha ${ }^{\mathrm{a}}$, Saad Mahmoud ${ }^{\mathrm{a}}$, Paul Anderson ${ }^{\mathrm{b}}$, Ahmed Elsayed ${ }^{\mathrm{c}}$ \\ ${ }^{a}$ Department of Mechanical Engineering, University of Birmingham, Birmingham, B15 2TT, United Kingdom. \\ ${ }^{\mathrm{b}}$ School of Chemistry, University of Birmingham, Birmingham, B15 2TT, United Kingdom. \\ ${ }^{\mathrm{c}}$ Department of Mechanical Engineering, Kingston University, SW15 3DW, United Kingdom. \\ *Corresponding author. E-mail: EXH496@alumni.bham.ac.uk; eng.eman.m.elsayed@gmail.com
}

\begin{abstract}
Many researchers consider adsorption systems as a solution for global problems such as global warming and water scarcity. The experimental and numerical data available in literature are basically focusing on using conventional adsorbent materials such as silica gel and zeolites. Recently, metal-organic framework (MOF) materials has been proposed to substitute these conventional adsorbents. Nevertheless, the potential of MOFs has been only numerically investigated without any experimental data from a real system. To fill this research gap, this work presents for the first time the experimental testing of a MOF material, aluminium fumarate, and how it can affect and enhance the performance of adsorption desalination systems. A parametric study to investigate the effect of different parameters such as chilled water, adsorption cooling water, condensation cooling water, desorption heating water temperatures and half cycle time on the performance of the adsorption system was developed. The suitability of the aluminium fumarate system for adsorption desalination was also assessed through analysing the quality of water produced from the system. Finally, the performance of the aluminium fumarate was also compared to conventional adsorbents such as silica gel. The superior performance of aluminium fumarate highlights the potential of the material in adsorption desalination application.
\end{abstract}


Keywords: Metal-organic framework, aluminium fumarate, experimental, adsorption desalination.

\section{Nomenclature}

Symbols

COP

$c_{p}$

$h_{f g}$

M

$\bullet$

$m$

$Q$

$S D W P$

$S C P$

$T$

$t$

$\tau$

\section{Subscripts}

a

chill

cond

des

evap

in

out

w
Description

\section{Unit}

Coefficient of performance

Specific heat at constant pressure

Latent heat of vapourization

Mass

Mass flow rate

Heat

Specific daily water production

Specific Cooling Power

Temperature

Time

number of cycles

$$
\begin{gathered}
\mathrm{J} \mathrm{kg}^{-1} \mathrm{~K}^{-1} \\
\mathrm{~J}(\mathrm{~kg} \mathrm{~K})^{-1} \\
\mathrm{~kg}
\end{gathered}
$$

$\mathrm{Kg} \mathrm{s}^{-1}$

$\mathrm{J} \mathrm{kg}^{-1}$

$\mathrm{m}^{3}$ (ton day) $)^{-1}$

$\mathrm{W} \mathrm{kg}{ }^{-1}$

K

$\mathrm{s}$

cycle

adsorbent material

chilled

condenser

desorption

evaporator

inlet

outlet

water

\section{Abbreviations}

$\mathrm{AlPO}_{4 \mathrm{~s}}$
AQSOA-ZO2
DVS
ED
GHG
MED
MOF
MSF
MVC
MIL

Aluminumphosphates

Aqua SOrb adsorbent

Dynamic vapour sorption

Electro-dialysis

Greenhouse gas

Multi-Effect Distillation

Metal-organic framework

Multi-Stage Flash

Mechanical Vapour Compression

Materials Institute Lavoisier 


$\begin{array}{cc}\text { RO } & \text { Reverse Osmosis } \\ \text { SAPOs } & \text { Silicoaluminumphosphates } \\ \text { SD } & \text { Solar Distillation } \\ \text { UoB } & \text { University of Birmingham } \\ \text { XRD } & \text { X-ray diffraction }\end{array}$

\section{Introduction}

Adsorption is a very old phenomenon, it was firstly observed by Scheele in 1773 [1] and Fontana in 1777 [2] reporting the adsorption of gases on charcoal and clays [3]. Later in time, de Saussure noticed that heat evolved during the process and that the porosity of the solid material is the main reason for the adsorption process to take place [4] and since then adsorption has been a prolific field with countless research studies as it can be used in numerous applications such as dehumidification, thermal batteries, and delivery of drinking water in remote areas [5-8] as water was produced from desert air using MOF-801 and MOF-303 [9]. Also, the adsorption technology has proven to be a sustainable system that has important advantages such as being driven by waste heat and low-grade heat sources such as solar energy and using environmentally friendly refrigerants such as water [10]. In a basic adsorption system (Fig. 1), the refrigerant (adsorbate) is evaporated, gaining its heat of evaporation from the surroundings producing useful cold (for refrigeration application). When the evaporator is connected to the adsorption bed, the vapour is adsorbed into the porous adsorbent material and generating the heat of adsorption. This heat can be either released to the surrounding in case of cooling applications or used as useful heat in heating application. In the desorption process, the porous adsorbent is dried through applying heat from an external heat source (low grade heat source). As the desorption bed is connected to the condenser, the desorbed refrigerant is condensed releasing its heat of condensation. This heat can be used in the heating application or is released to the surrounding in cooling applications [11]. 


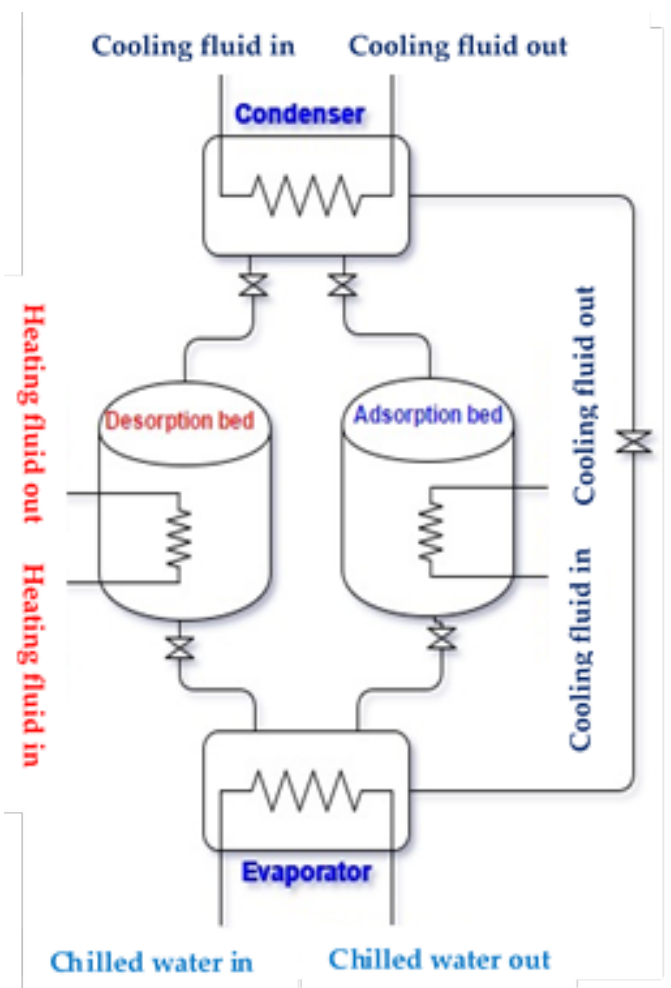

Fig. 1 Adsorption system.

Physical adsorbents are porous materials with different pore size and topologies that adsorb gases through Vander Waals forces and retain their original properties during the adsorption and desorption processes. The criteria in the selection of the adsorbent/adsorbate pair include affinity of the pair for each other, pore size, surface area, toxicity, thermal and chemical stability, corrosiveness, thermal conductivity, diffusivity, heat of adsorption, heat of evaporation, availability and cost. Activated carbon, silica gel, zeolites, zeolite-like materials (aluminumphosphates $\left(\mathrm{AlPO}_{4} \mathrm{~s}\right)$ and silicoaluminumphosphates (SAPOs)) are the most common commercially available adsorbents [12].

Water is considered as the most used adsorbate. This is attributed to the fact that water has high latent heat of vaporization, being environmentally friendly, being thermally stable at a wide range of operating conditions and with a wide range of adsorbent materials, and also its availability is an essential advantage $[13,14]$. Fig. 2 shows the water vapour uptake by different adsorbent materials. It can be noticed that all the materials possess an uptake less than 0.3 while Zeolite $13 \mathrm{X}$ is the only material with an uptake of $0.35 \mathrm{~g}_{\mathrm{H}_{2} \mathrm{O}} \mathrm{g}_{\mathrm{ads}}{ }^{-1}$ at a relative pressure of 0.5 . 


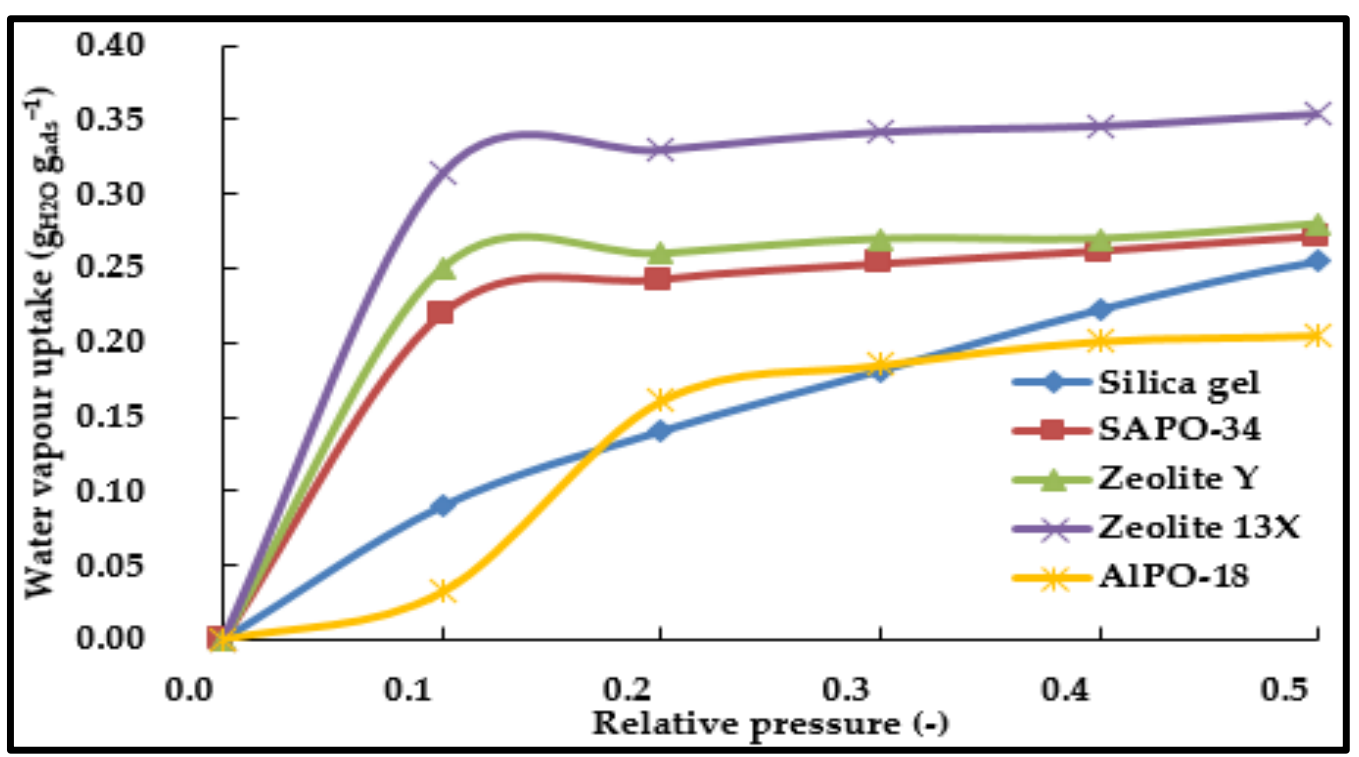

Fig. 2 Water adsorption isotherms of conventional adsorbents such as silica gel RD [15], SAPO-34 [16], Zeolite Y [17], Zeolite 13X [18] and AIPO-18 [18] at $25^{\circ} \mathrm{C}$.

Adsorption technology can offer an innovative solution to another global crisis which is water scarcity. Globally, there are seven hundred million people who are suffering from water scarcity, while another 500 million are approaching this situation. This situation is expected to worsen by 2025 as 1.8 billion people will be living in regions with absolute water scarcity [19]. Desalination has become a well-known technology across the world. It is the process by which seawater with high total dissolved solids content $(>35,000 \mathrm{ppm})$ is used to produce potable water. Desalination technologies can be categorised into (1) membrane technologies which include pressure activated systems such as the Reverse Osmosis (RO) or electrical activated systems such as Electro-dialysis (ED); (2) thermal energy systems (distillation processes) such as the Multi-Stage Flash (MSF), Multi-Effect Distillation (MED), Mechanical Vapour Compression (MVC) and Solar Distillation (SD) and (3) chemical methods such as Ion-Exchange Desalination and Gas Hydrate [20]. The most used technologies are the RO, ED, MSF and MED.

Due to the extensive energy consumption of the MSF and MED compared to the RO techniques (Table 1), hybrid desalination systems that combine thermal and membrane processes were 
proposed. Such systems offer the operation flexibility and lower energy consumption which would result in lower greenhouse gas (GHG) emissions [21, 22]. Combining RO with MED and MSF systems compensates the inflexibility of MSF and MED and reduces the posttreatment costs [21].

Table 1 Energy consumption and GHG emissions of desalination techniques

\begin{tabular}{|c|c|c|c|c|c|}
\hline & 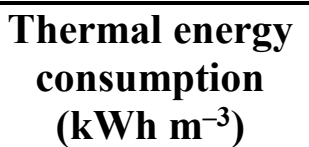 & $\begin{array}{c}\text { Electrical energy } \\
\text { consumption } \\
\left(\mathrm{kWh} \mathrm{m}^{-3}\right)\end{array}$ & $\begin{array}{c}\mathrm{CO}_{2} \\
\text { emissions } \\
\left(\mathrm{kg} \mathrm{m}^{-3}\right)\end{array}$ & $\begin{array}{c}\text { Cost } \\
\left(\$ \mathbf{~ m}^{-3}\right)\end{array}$ & Ref. \\
\hline RO & 0 & $4-8$ & 2.79 & 0.76 & \multirow{3}{*}{ 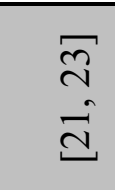 } \\
\hline MED & $41.67-61.11$ & $1.5-5$ & $11.8-17.6$ & 0.83 & \\
\hline MSF & $69.44-83.33$ & $3.5-5$ & $20.4-25.0$ & 1.07 & \\
\hline Adsorption & 39.8 & 1.38 & 11.2 & 0.3 & [24] \\
\hline
\end{tabular}

Due to the high GHG emissions of the conventional desalination methods and its effect on the global warming phenomenon, new technologies with lower energy consumption and $\mathrm{CO}_{2}$ emissions are needed. Recently, adsorption desalination has gained significant attention due to its many advantages such as the low energy consumption as shown in Table $\mathbf{1}[22,24]$, using environmentally friendly refrigerants, being operated by waste or renewable heat sources, using low evaporation temperature hence reducing the fouling effect (formation of scales which may cause the evaporation unit damage). Also, adsorption desalination system can produce not only high-grade distilled water but also cooling effect using the same heat source [20].

The desalination adsorption system consists of adsorption/desorption beds, a condenser and an evaporator. Each bed contains finned tube heat exchangers with the adsorbent material packed between the fins [20]. For a two-bed system, the first bed works as an adsorption bed while the other works as a desorption bed. After the half cycle time, the operation mode is reversed. At the beginning of the cycle, an evaporation-adsorption process takes place where the seawater is evaporated due to the affinity of the adsorbent resulting in the cooling effect from the evaporator. Heat of adsorption is evolved and transferred to the cooling water in the adsorption bed. During the desorption-condensation processes, the low-grade heat is supplied to the 
desorption bed to remove the adsorbed water vapour. As the desorption bed and condenser are connected, the water vapour migrates to the condenser where the vapour is condensed and the desalinated water is collected [25]. Due to the limited circulated refrigerant and low water uptake of currently used adsorbent materials at low relative pressure range, the adsorption system suffers from low coefficient of performance (COP), specific cooling power (SCP) and specific daily water production (SDWP). As shown in Table 2, numerous studies of adsorption desalination have been conducted since its appearance in 2006 [26]. It can be noticed that most systems use silica gel as the adsorbent material giving a maximum SDWP of $10 \mathrm{~m}^{3}$ (ton day) ${ }^{-1}$ for a 4-bed system. A heat recovery cycle was later developed where the latent heat of condensation was recovered into the evaporator through building the two units inside each other. This approach increased the SDWP to $26 \mathrm{~m}^{3}$ (ton day) ${ }^{-1}$. Kim et al. [27] assessed the water quality produced from a silica gel adsorption desalination system. Results showed that the total dissolved solids decreased from more than 40,000 ppm to almost zero while other parameters such as turbidity, $\mathrm{pH}$, hardness, alkalinity, conductivity and elemental analysis proved the production of high-quality distilled water from the system. A feasibility study of the system was held by $\mathrm{Ng}$ et al. [24] showing that adsorption desalination required less unit production cost, electrical energy and total primary energy than other conventional desalination systems.

The long dominating silica gel was replaced by AQSOA-ZO2 (Aqua SOrb adsorbent) in a SIMULINK model for a two-bed adsorption system developed by Youssef et al. [28] showing that at high chilled water temperature $\left(>20^{\circ} \mathrm{C}\right)$, silica-gel outperformed AQSOA-ZO2 while at chilled water temperature $<20^{\circ} \mathrm{C}$, the situation was reversed.

Another technique that was recently proposed to enhance the performance and water production of the adsorption system is hybridization where the system can be a combination of two systems such as adsorption desalination and multi-effect distillation [29]. Also, another 
proposed solution is replacing the conventional adsorbent materials with advanced adsorbents that exhibit higher water capacity and hence a higher distilled water production and better system performance to be expected [20].

Table 2 SDWP and SCP of some of previously developed adsorption desalination systems

\begin{tabular}{|c|c|c|c|c|c|c|c|}
\hline Adsorbent & $\begin{array}{l}\text { No. of } \\
\text { beds }\end{array}$ & $\begin{array}{c}\text { SDWP } \\
\mathbf{m}^{3}(\text { ton day })^{-1}\end{array}$ & $\begin{array}{c}\text { SCP } \\
\text { Rton ton }^{-1}\end{array}$ & $\begin{array}{l}\mathbf{T}_{\text {eva }} \\
\left({ }^{\circ} \mathrm{C}\right)\end{array}$ & $\begin{array}{l}T_{\text {reg }} \\
\left({ }^{\circ} \mathbf{C}\right)\end{array}$ & $\begin{array}{l}\text { Half cycle } \\
\text { time } \\
\text { (s) }\end{array}$ & Ref. \\
\hline Silica gel & 2 & 4.2 & 27.5 & 15 & 85 & 600 & [30] \\
\hline Silica gel & 2 and 4 & 8.8 and 10 & - & 30 & 85 & $600-500$ & [31] \\
\hline Silica gel & 4 & 7.8 & 51 & 30 & 85 & 480 & [32] \\
\hline Silica gel & 4 & 2.4 & 18 & 30 & 85 & 600 & [33] \\
\hline Silica gel & 2 & 9.3 & - & $<32$ & 70 & 570 & [34] \\
\hline Silica gel & 4 & 26 & - & $<42$ & 85 & 300 & [35] \\
\hline $\begin{array}{l}\text { AQSOA- } \\
\text { Z02 }\end{array}$ & 4 & 7.5 & 58 & 30 & 85 & 300 & [36] \\
\hline
\end{tabular}

As most of the published studies are mainly focusing on conventional adsorbents such as silica gel and zeolites which suffer from previously highlighted problems, new adsorbent materials with improved adsorption properties are needed. Metal-organic framework materials have been used in producing and delivery of drinking water in remote areas [5-8] as water was produced from desert air using MOF-801 and MOF-303 [9].

This work aims to fill the gap in research shaped by the previous problems through experimentally investigating the potential of advanced metal-organic framework (MOF) material, aluminum fumarate, in different adsorption applications such as desalination and heat pump. Aluminium fumarate has been numerically investigated in a number of studies $[20,37-$ 39] in which its performance was compared to systems using conventional silica gel. These studies highlighted how the adsorption technology is an energy efficient approach and the system performance can be furtherly enhanced through using this class of materials compared to silica gel and zeolite. Nevertheless, there have not been any experimental testing of an 
adsorption system employing aluminium fumarate and how it can affect the specific daily water production (SDWP) or the water quality produced from the system. In this study, experimental testing of aluminium fumarate was carried out to fill this gap of research. The performance of aluminum fumarate was then compared to the performance of conventional adsorbent materials such as silica gel to highlight the potential of using aluminium fumarate in adsorption desalination system. The adsorption system was tested at different operating conditions through varying the half cycle time, the chilled water, adsorption bed cooling water, condenser cooling water and desorption bed heating water temperatures to determine the optimum operating conditions for different adsorption applications.

\subsection{Aluminium fumarate:}

Physical adsorbents are porous materials with different pore size and topologies that adsorb gases through Vander Waals forces and retain their original properties during the adsorption and desorption processes. The main criteria in the selection of the adsorbent/adsorbate pair include affinity of the pair for each other, pore size, surface area, stability, regeneration temperature and availability [12].

Aluminium fumarate is a microporous MOF material that is also known as Basolite ${ }^{\mathrm{TM}}$ A520. The Al-OH-Al nodes are linked to the fumarate moiety to form a rhombohedral channels that structurally resembles MIL-53 [40] (Fig. 3). The material is synthesized from aluminium chloride or nitrate and fumaric acid at $130^{\circ} \mathrm{C}$ for 4 days at atmospheric pressure [40, 41] or $130^{\circ} \mathrm{C}$ for $15 \mathrm{~min}$ using microwave irradiation [42]. With its hydrothermal and cyclic stability, low desorption temperature and high surface area and pore size that offer a maximum water vapour uptake of $0.55 \mathrm{~g}_{\mathrm{H} 2 \mathrm{O}} \mathrm{gads}^{-1}$, aluminium fumarate is considered as a good candidate for adsorption heat pump and desalination applications. Aluminium fumarate also offers another important advantage which is the potential of being synthesized on a large scale by an easy and reproducible synthesis approach [43], hence the material is commercially available. 
Aluminium fumarate in this study was synthesized and commercially provided by MOF Technologies Ltd, UK.
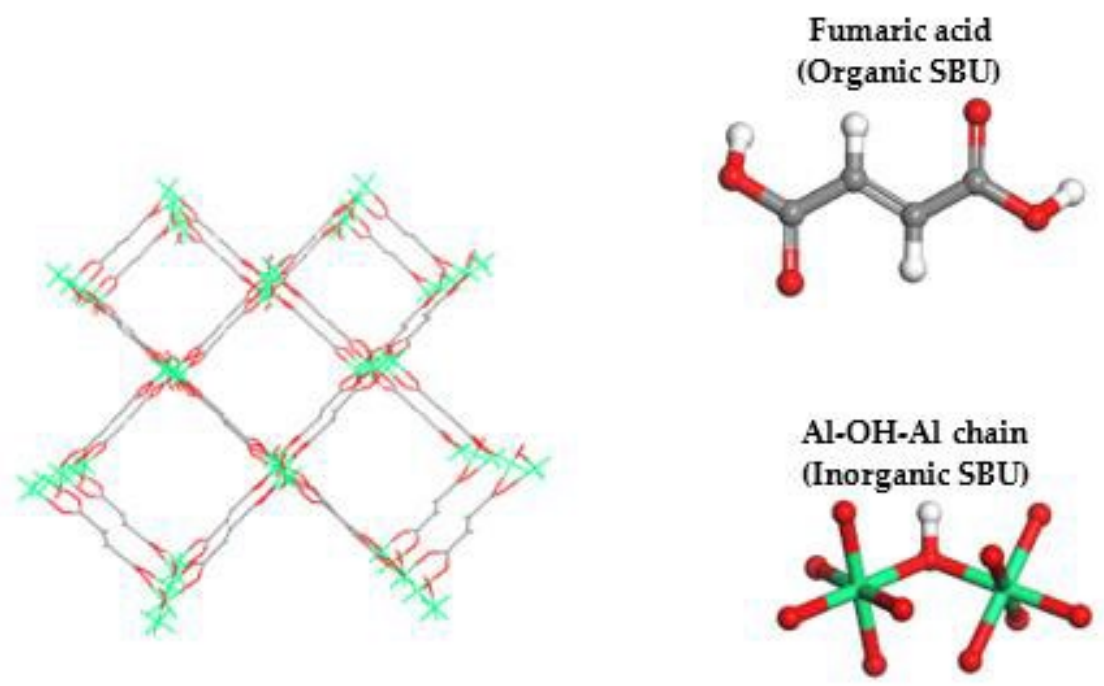

Fig. 3 Crystal structure and secondary building units of aluminium fumarate. (Figure was developed using Materials Studio software)

It was studied by Jeremias et al [40] through synthesizing a MOF coating layer on a metal substrate via the thermal gradient approach. The study showed that aluminium fumarate has a potential in adsorption applications as it can be regenerated at a significantly low temperature and it has a water loading difference of $0.53 \mathrm{~g}_{\mathrm{H} 2 \mathrm{O}} \mathrm{gads}^{-1}$. Kummer et al [44] developed a heat exchanger coated with the microporous aluminium fumarate using a polysiloxane-based binding agent. The heat exchanger produced an average cooling power of $690 \mathrm{~W}$ under the working conditions of an adsorption chiller working at a desorption temperature of $90{ }^{\circ} \mathrm{C}$, a condenser and adsorption temperature of $30^{\circ} \mathrm{C}$ and a chilled water temperature of $18{ }^{\circ} \mathrm{C}$.

The material was fully characterized in our previous work through powder X-Ray Diffraction (XRD), nitrogen adsorption and their water adsorption properties [20, 37]. Due to its highwater vapour capacity, performance stability and low desorption temperature [20, 37], 
aluminium fumarate was chosen to be experimentally tested for the first time in a full adsorption system.

\section{Test facility description}

Fig. 4 shows a schematic diagram and a pictorial presentation of the experimental test facility. As it can be noticed, the main components of the system are two identical adsorption beds, an evaporator and a condenser. Each bed is fitted with two fin and tube heat exchangers packed with $0.375 \mathrm{~kg} /$ heat exchanger of aluminium fumarate which means a total aluminium fumarate mass of $1.5 \mathrm{~kg}$ in the two adsorption beds.

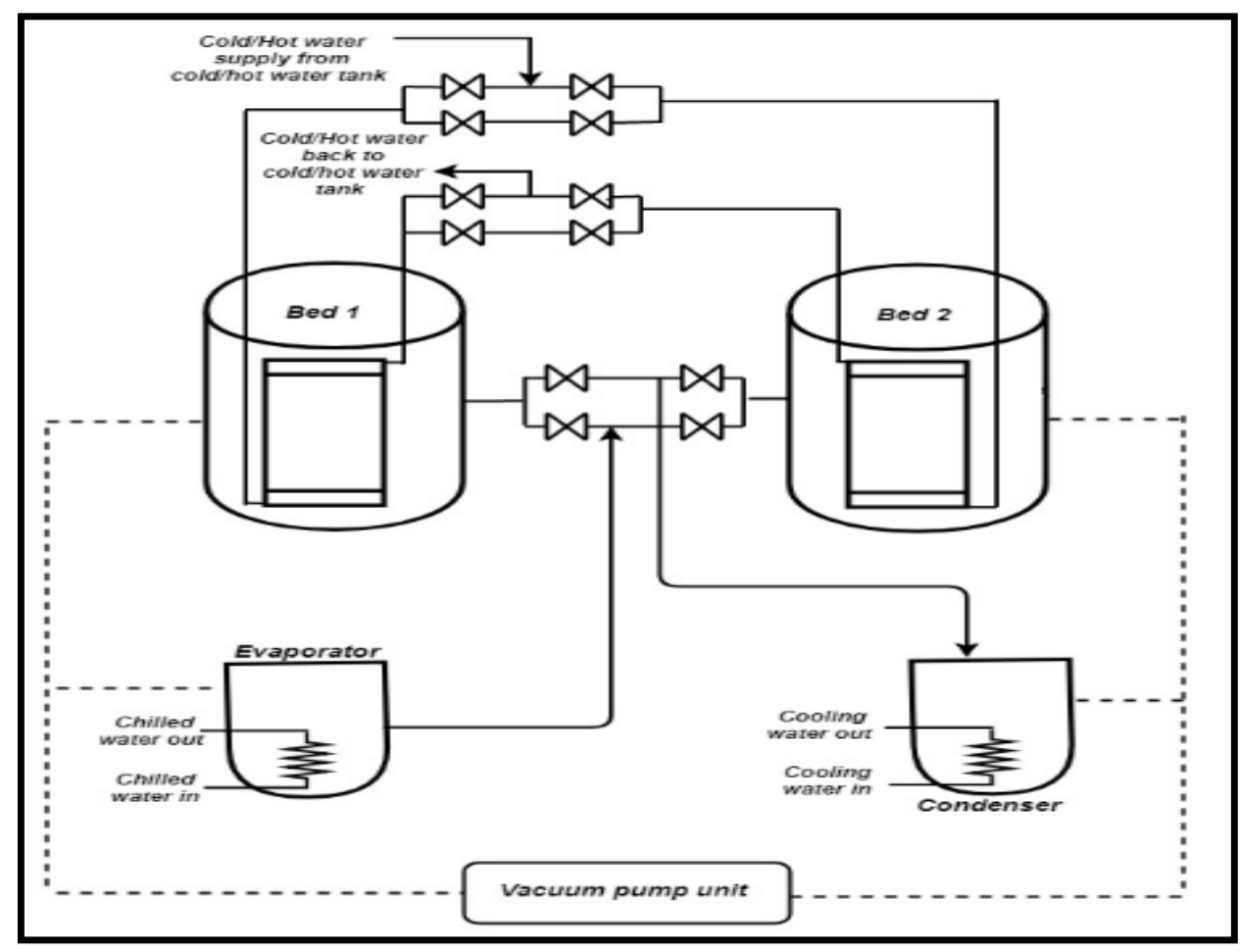




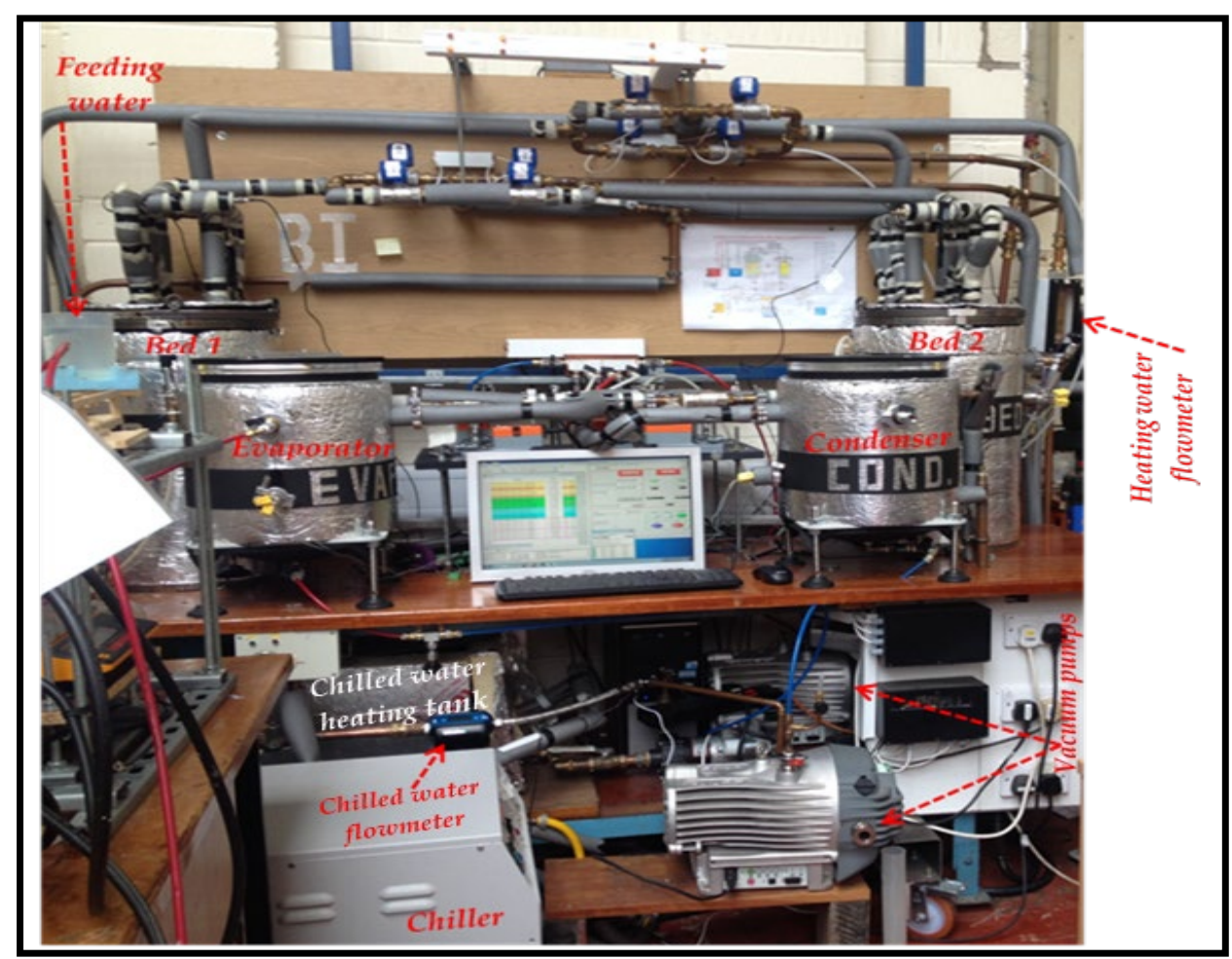

Fig. 4 Schematic diagram and pictorial presentation of the 2-bed system test facility.

2.1. Adsorption bedThe adsorption/desorption bed is the main component in any adsorption system. During the adsorption phase, the bed is connected to the evaporator to adsorb the water vapour while during the desorption phase, the bed is connected to the condenser to desorb the vapour. Each bed consists of a cylindrical steel vessel where pressure transducers and thermocouples are fitted. Each vessel contained two heat exchangers with six copper tubes that are connected to hot/cold water supply header and the return water pipe (Fig. 5a) with the dimensions shown in Table 3. The adsorbent granules (Fig. 5b) were packed between the fins (Fig. 5a) and then covered with a metallic mesh from the two sides to prevent the displacement of the adsorbent granules. 

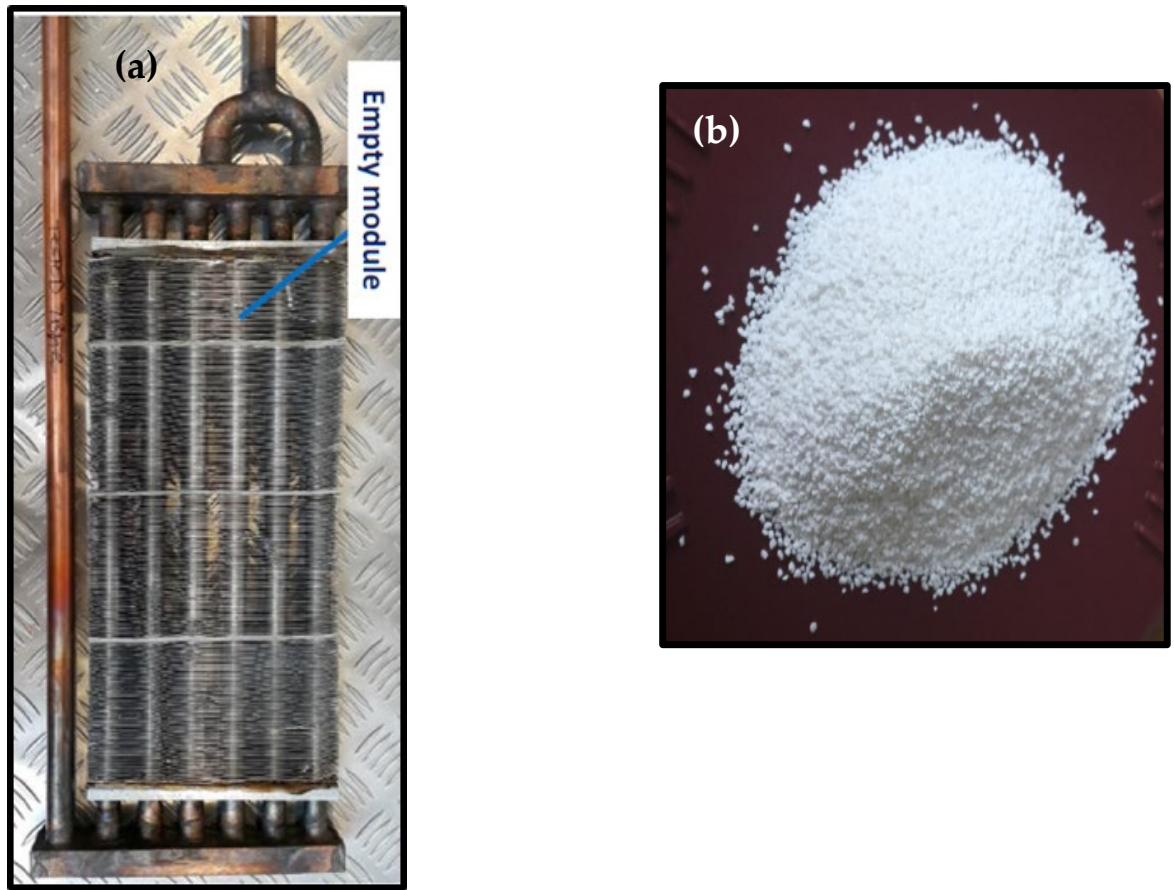

Fig. 5 a. fin and tube heat exchanger and b. aluminium fumarate granules.

Table 3 Dimensions of aluminium fumarate heat exchangers:

\begin{tabular}{lcc}
$\begin{array}{l}\text { Parameter } \\
\text { Length }\end{array}$ & Units & Value \\
\hline Fin width & $\mathrm{m}$ & $350 \mathrm{E}-3$ \\
\hline Fin height & $\mathrm{m}$ & $173 \mathrm{E}-3$ \\
\hline Fin pitch & $\mathrm{m}$ & $30 \mathrm{E}-3$ \\
\hline Fin thickness & $\mathrm{m}$ & $1.0 \mathrm{E}-3$ \\
\hline Tube outer diameter & $\mathrm{m}$ & $0.1 \mathrm{E}-3$ \\
\hline $\begin{array}{l}\text { Tube thickness } \\
\text { Number of fins in one heat } \\
\text { exchanger }\end{array}$ & $\mathrm{m}$ & $15.87 \mathrm{E}-3$ \\
\hline $\begin{array}{l}\text { Adorbent/heat exchanger } \\
\text { No of heat exchangers/bed }\end{array}$ & - & $0.8 \mathrm{E}-3$ \\
\hline
\end{tabular}




\subsection{Evaporator}

Another essential part of the adsorption system is the evaporator where the evaporation of water (seawater in case of adsorption desalination application) takes place. The Evaporator used in this study consisted of a stainless-steel vacuum chamber with a two-level helical coil formed using $10 \mathrm{~m}$ of $8 \mathrm{~mm}$ outer diameter copper tube working as the chilled water circuit.

\subsection{Condenser}

The condenser is where the desorbed water vapour is condensed to produce distilled water in case of desalination or sent back to the evaporator in case of heat pump applications. It consisted of a stainless-steel shell and a helical copper coil. The stainless-steel shell is identical to the one used in the evaporator with the copper coil consists of two spiral coils, one inside the other formed from a $10 \mathrm{~m}$ of $8 \mathrm{~mm}$ outer diameter copper tube.

\section{Aluminium fumarate experimental results}

The suitability of aluminium fumarate for different adsorption desalination application was assessed through investigating the effect of different parameters on the performance of a two-bed system. The parameters included half cycle time, chilled water, condenser cooling water, adsorption bed cooling water and desorption bed heating water temperatures. The operating conditions used in this study are shown in Table 4.

Table. 4 Aluminium fumarate operating conditions

\begin{tabular}{lcc}
\hline Parameter & Units & Value \\
\hline Chilled water inlet temperature & ${ }^{\circ} \mathrm{C}$ & $10,15,20$ and 30 \\
\hline Adsorption bed cooling water inlet temperature & ${ }^{\circ} \mathrm{C}$ & $24,30,40$ and 50 \\
\hline Condenser cooling water inlet temperature & ${ }^{\circ} \mathrm{C}$ & $20,30,40$ and 50 \\
\hline Desorption bed heating water inlet temperature & ${ }^{\circ} \mathrm{C}$ & 70,80 and 90 \\
\hline Half cycle time & $\mathrm{S}$ & $500,700,900$ and 1100 \\
\hline Switching time & $\mathrm{S}$ & 70 \\
\hline Adsorption bed cooling water flowrate & $\mathrm{L} \mathrm{min}{ }^{-1}$ & 17 \\
\hline
\end{tabular}




\begin{tabular}{lcc} 
Adsorption bed heating water flowrate & $\mathrm{L} \mathrm{min}^{-1}$ & 20 \\
\hline Chilled water flowrate & $\mathrm{L} \mathrm{min}^{-1}$ & 3.25 \\
\hline Condenser cooling water flowrate & $\mathrm{L} \mathrm{min}^{-1}$ & 3.5 \\
\hline Adsorbent/heat exchanger & $\mathrm{kg}$ & 0.375 \\
\hline No of heat exchangers/bed & - & 2 \\
\hline
\end{tabular}

\subsection{Effect of operating conditions on the performance of aluminium fumarate} system:

\subsubsection{Effect of chilled water inlet temperature:}

Fig. 6 shows the effect of the chilled water inlet temperature on the performance of aluminium fumarate through assessing the specific daily water production (SDWP) using Eq. $\mathbf{3}$ and the specific cooling power (SCP) as a secondary product using Eq. 5.

$$
\begin{aligned}
& Q_{\text {cond }}=\frac{m_{\text {cooling }}^{\cdot} C_{p_{w}} \int_{0}^{t_{\text {cvcle }}}\left(T_{\text {cooling, in }}-T_{\text {cooling, out }}\right) d t}{t_{\text {cycle }}} \\
& \tau=\frac{24 \times 60 \times 60}{t_{\text {cycle }}} \\
& S D W P=\int_{0}^{t_{\text {cycle }}} \frac{Q_{\text {cond }} \tau}{h_{f g} M_{a}} d t \\
& Q_{\text {evap }}=\frac{m_{\text {chill }}^{\bullet} C_{p_{w}} \int_{0}^{t_{\text {cycle }}}\left(T_{\text {chill, in }}-T_{\text {chill,out }}\right) d t}{t_{\text {cycle }}} \\
& S C P=\int_{0}^{t_{\text {cycle }}} \frac{Q_{\text {evap }}}{M_{a}} d t
\end{aligned}
$$

It can be noticed that increasing the chilled water inlet temperature significantly improved the performance as the SDWP increased from only 2.6 at $10^{\circ} \mathrm{C}$ to $6.8 \mathrm{~m}^{3}$ ton $^{-1} \mathrm{day}^{-1}$ at $20^{\circ} \mathrm{C}$ and the SCP increased from $65 \mathrm{~W} \mathrm{~kg}^{-1}$ to $191 \mathrm{~W} \mathrm{~kg}^{-1}$ at the same temperatures. For adsorption desalination application without cooling effect, the material showed it can produce up to $12 \mathrm{~m}^{3}$ ton $^{-1}$ day $^{-1}$ working at a chilled water inlet temperature of $29^{\circ} \mathrm{C}$. 
This can be explained by the material adsorption isotherm shape (Fig. 7) [20, 37] showing that the material possesses a type IV isotherm where the material uptake increases significantly with increasing the chilled water inlet temperature or the working relative pressure [20].

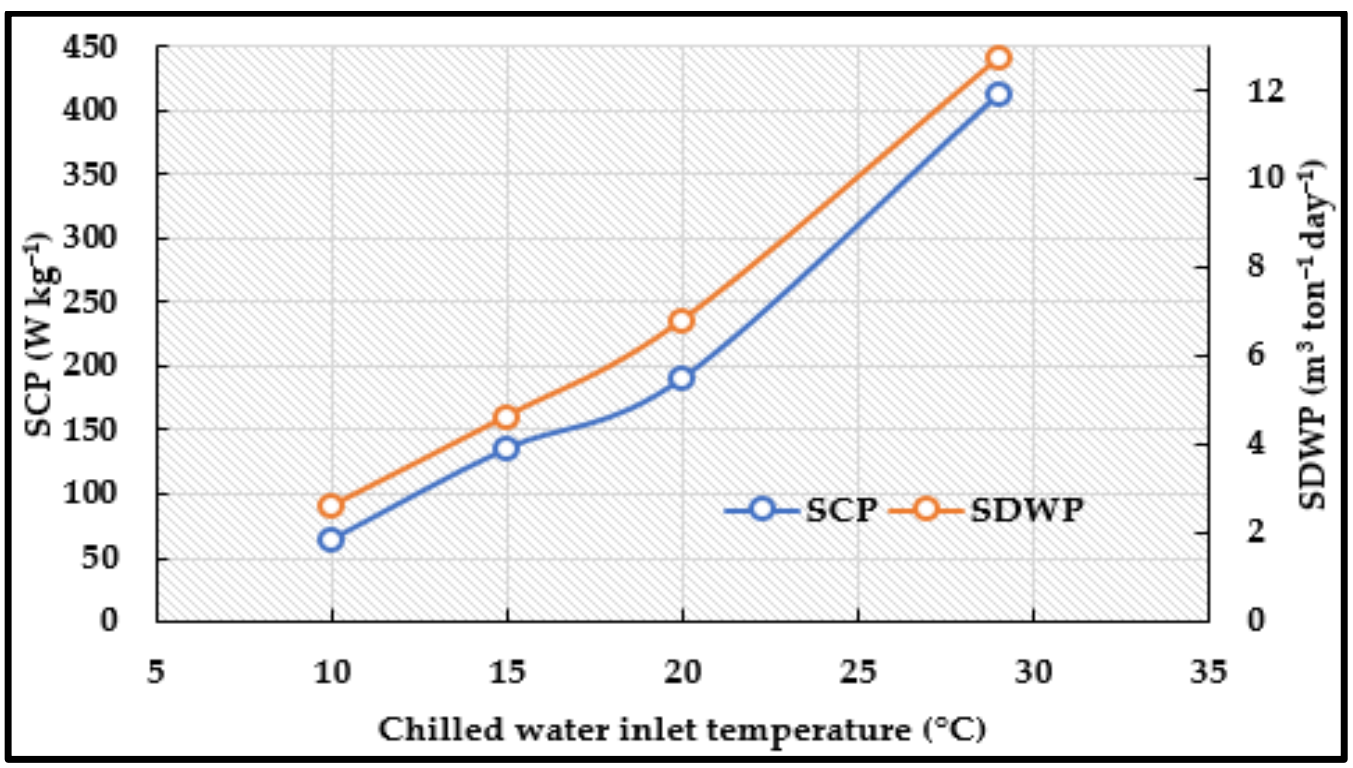

Fig. 6 Effect of chilled water inlet temperature on the performance of aluminium fumarate desalination system.

$\left(T_{\text {ads }}=30^{\circ} \mathrm{C}, T_{\text {cond }}=30^{\circ} \mathrm{C}, T_{\text {des }}=90^{\circ} \mathrm{C}\right.$, half cycle time $=700 \mathrm{~s}$ and $\left.t_{\text {switching }}=70 \mathrm{~s}\right)$.

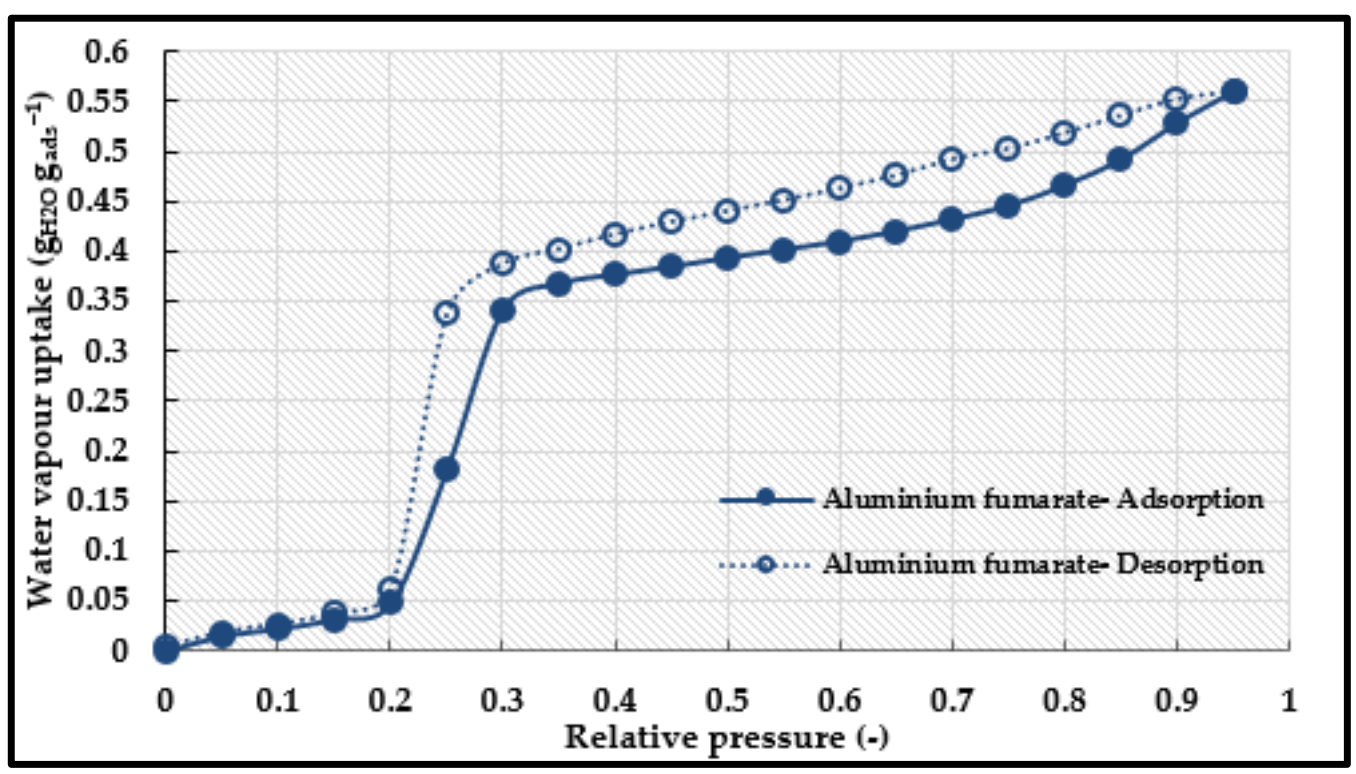

Fig. 7 Water adsorption isotherm of aluminium fumarate at $25^{\circ} \mathrm{C}[20,37]$.

\subsubsection{Effect of half cycle time:}

Optimum half cycle time is a crucial parameter that significantly affects the adsorption system performance. Short cycle time results in poor performance as the adsorbent material 
does not have sufficient time to adsorb/desorb the water vapour while prolonged cycle time is accompanied with a decrease in the performance due to that the increase in the adsorbed water vapour does not compensate for the increase in cycle time. This is evident in Fig. 8 where at short half cycle times, both the SDWP and SCP are low, but they increase to reach their maximum values at optimum half cycle time of $900 \mathrm{~s}$. At such time, the material achieved an SDWP of $8.5 \mathrm{~m}^{3}$ ton $^{-1} \mathrm{day}^{-1}$ and SCP of $245 \mathrm{~W} \mathrm{~kg}^{-1}$ and. At a longer half cycle time, both SDWP and SCP start to decrease. Based on these results, an optimum half cycle time of $900 \mathrm{~s}$ was chosen to be further investigated.

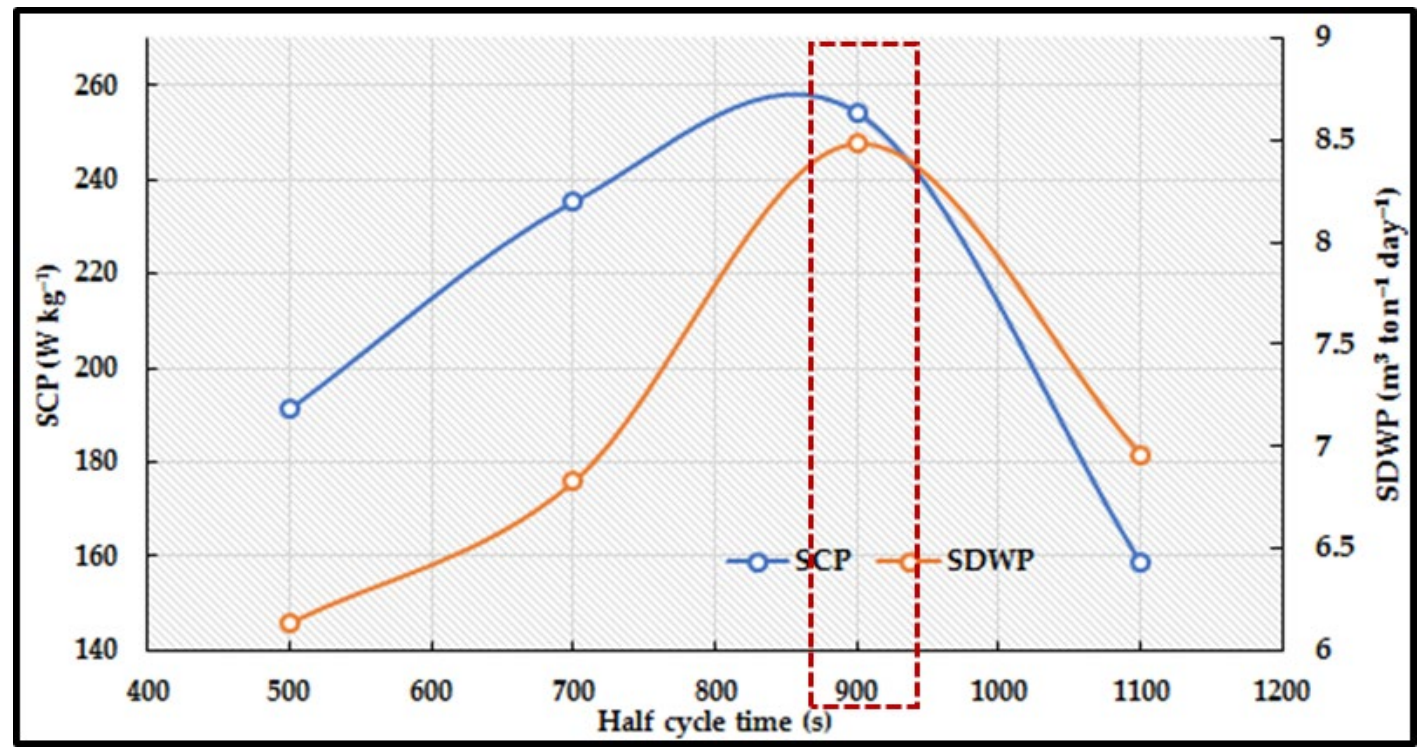

Fig. 8 Effect of half cycle time on the performance of aluminium fumarate desalination system.

$\left(T_{\text {ads }}=30^{\circ} \mathrm{C}, \mathrm{T}_{\text {cond }}=30^{\circ} \mathrm{C}, \mathrm{T}_{\text {des }}=90^{\circ} \mathrm{C}, \mathrm{T}_{\text {eva }}=20^{\circ} \mathrm{C}\right.$ and $\left.t_{\text {switching }}=70 \mathrm{~s}\right)$.

\subsubsection{Effect of adsorption bed cooling water inlet temperature:}

Another important parameter is the adsorption temperature. Fig. 9 depicts the effect of the adsorption bed cooling water inlet temperature on the performance of the system. It can be noticed that as the temperature increased from 24 to $50^{\circ} \mathrm{C}$ the SDWP decreased from 9.7 to only $1.2 \mathrm{~m}^{3}$ ton $^{-1}$ day $^{-1}$ while the SCP decreased from 318 to $20.5 \mathrm{~W} \mathrm{~kg}^{-1}$. This shows that increasing the adsorption bed cooling water inlet temperature adversely affects the performance of the system. Increasing the adsorption bed cooling water temperature means decreasing the 
working relative pressure and as highlighted earlier (Fig. 7), the performance of aluminium fumarate significantly depends on the working relative pressure.

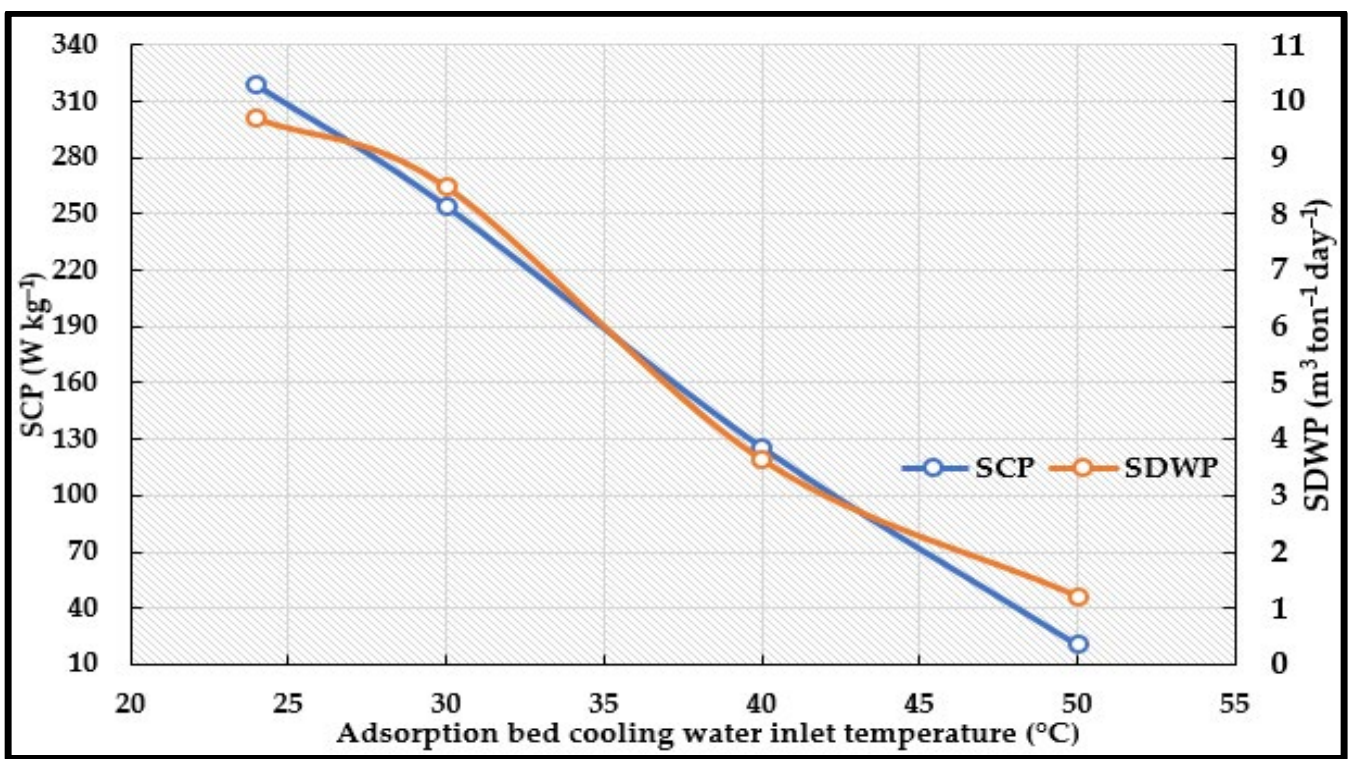

Fig. 9 Effect of adsorption bed cooling water inlet temperature on the performance of aluminium fumarate desalination system.

$\left(T_{\text {cond }}=30^{\circ} \mathrm{C}, \mathrm{T}_{\mathrm{des}}=90^{\circ} \mathrm{C}, \mathrm{T}_{\mathrm{eva}}=20^{\circ} \mathrm{C}\right.$, half cycle time $=900 \mathrm{~s}$ and $\left.\mathrm{t}_{\text {switching }}=70 \mathrm{~s}\right)$.

\subsubsection{Effect of condenser cooling water inlet temperature:}

The effect of the condensation temperature is shown in Fig. 10 where it can be seen that increasing the condenser cooling water inlet temperature adversely affects both SCP and SDWP. Increasing the condenser cooling water inlet temperature from 20 to $50^{\circ} \mathrm{C}$ decreased the SDWP from 9 to $4 \mathrm{~m}^{3}$ ton $^{-1}$ day $^{-1}$ while the SCP decreased from 265 to $141 \mathrm{~W} \mathrm{~kg}^{-1}$. This is attributed to that as the condenser cooling water inlet temperature increases, the condenser pressure increases retarding the water vapour flow from the bed to the condenser and hence result in an incomplete desorption process. The incomplete desorption may lead to that the material does not reach its capacity during the next adsorption phase. 


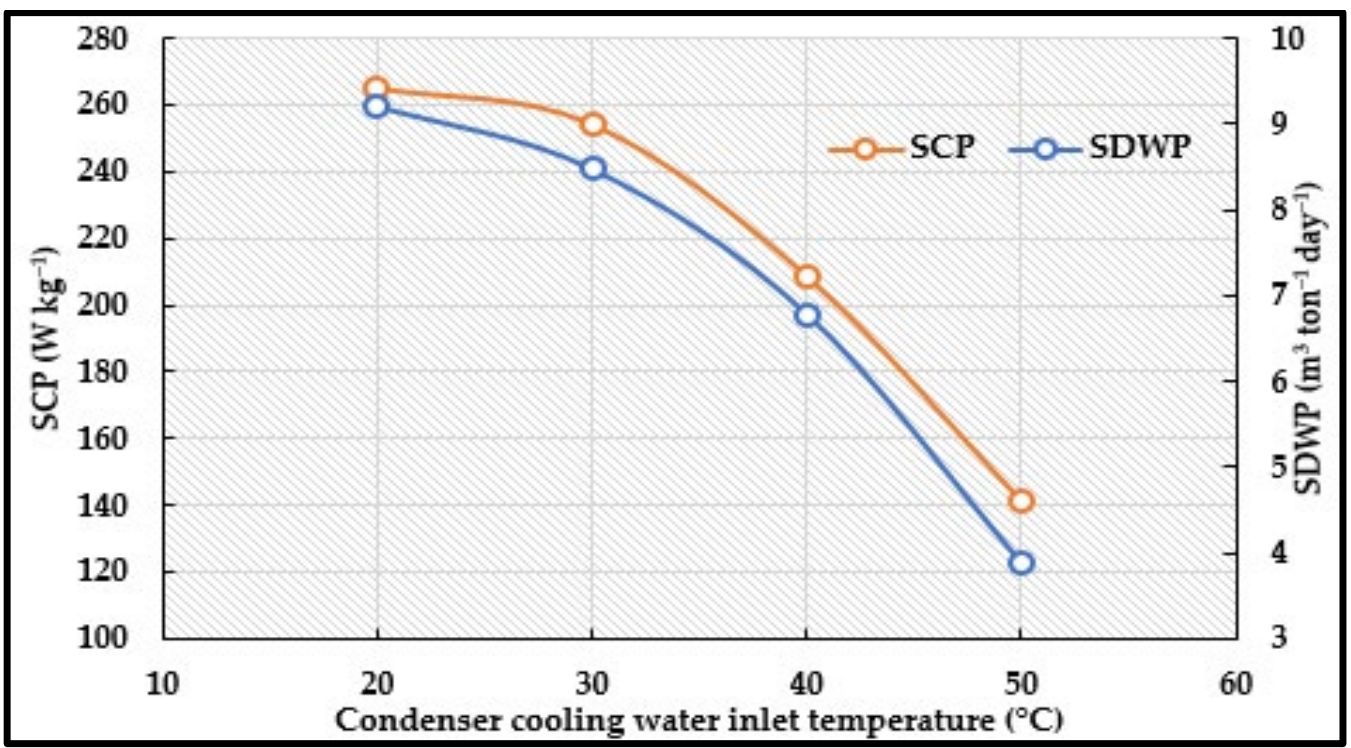

Fig. 10 Effect of condenser cooling water inlet temperature on the performance of aluminium fumarate desalination system.

$\left(\mathrm{T}_{\text {ads }}=30^{\circ} \mathrm{C}, \mathrm{T}_{\mathrm{des}}=90^{\circ} \mathrm{C}, \mathrm{T}_{\mathrm{eva}}=20^{\circ} \mathrm{C}\right.$, half cycle time $=900 \mathrm{~s}$ and $\left.\mathrm{t}_{\text {switching }}=70 \mathrm{~s}\right)$.

\subsubsection{Effect of desorption bed heating water inlet temperature:}

The low desorption temperature required to regenerate aluminium fumarate is highlighted through Fig. 11. It can be noticed that increasing the desorption bed hot water inlet temperature from $70^{\circ} \mathrm{C}$ to $90^{\circ} \mathrm{C}$ slightly increased the SDWP from 8.2 to $8.5 \mathrm{~m}^{3}$ ton $^{-1}$ day $^{-1}$ while the SCP increased from 246 to $254 \mathrm{~W} \mathrm{~kg}^{-1}$. This highlights the potential of aluminium fumarate in adsorption applications working with low temperature heat sources.

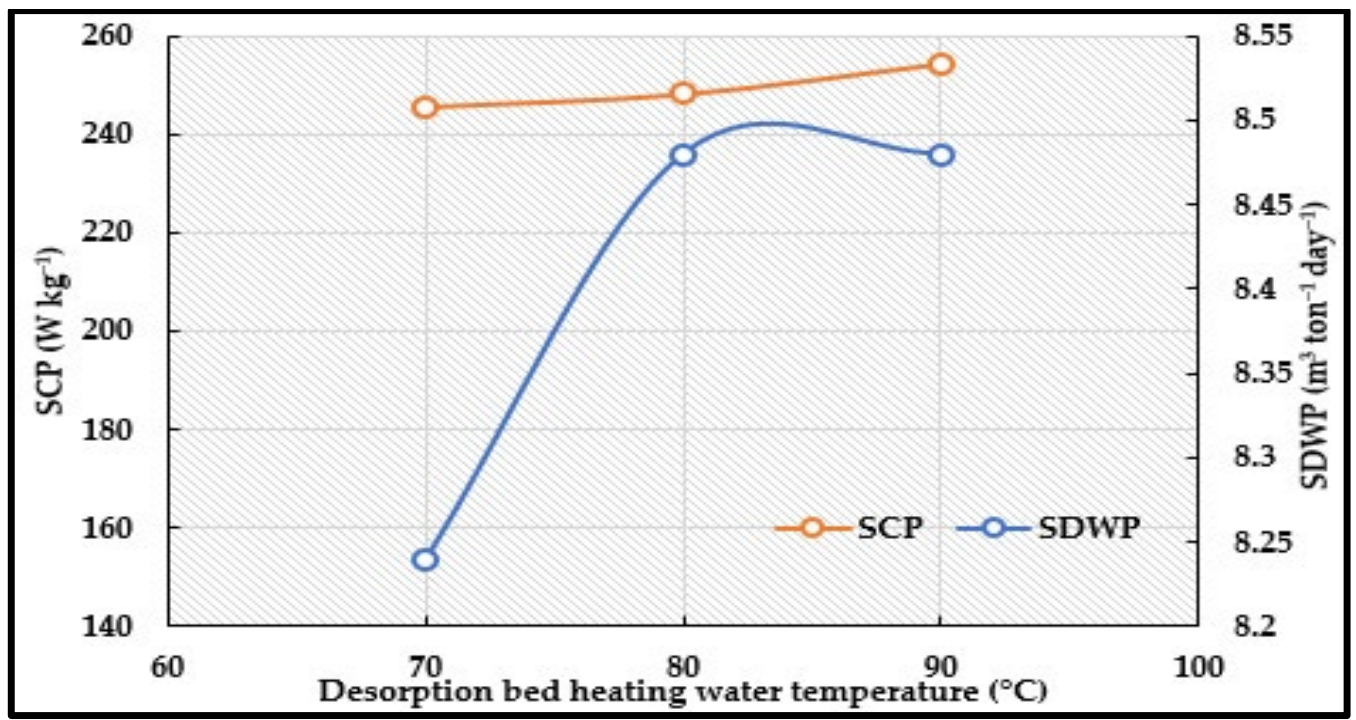

Fig. 11 Effect of desorption bed heating water inlet temperature on the performance of aluminium fumarate desalination system.

$\left(\mathrm{T}_{\mathrm{ads}}=30^{\circ} \mathrm{C}, \mathrm{T}_{\text {cond }}=30^{\circ} \mathrm{C}, \mathrm{T}_{\mathrm{eva}}=20^{\circ} \mathrm{C}\right.$, half cycle time $=900 \mathrm{~s}$ and $\left.\mathrm{t}_{\text {switching }}=70 \mathrm{~s}\right)$. 


\section{Aluminium fumarate in adsorption desalination application:}

Based on the data presented in Fig.6 to Fig.11, the suitability of aluminium fumarate for desalination adsorption application was assessed at the investigated temperature ranges summarized in Table $\mathbf{5 .}$

Table 5 Aluminium fumarate in adsorption desalination application:

\begin{tabular}{cccccc}
\hline Application & & & & & \\
\hline $\begin{array}{c}\text { Chill. Water } \\
\text { Temp. }\end{array}$ & $\begin{array}{c}\text { Ads. } \\
\text { Temp. }\end{array}$ & $\begin{array}{c}\text { Cond. } \\
\text { Temp. }\end{array}$ & $\begin{array}{c}\text { Des. } \\
\text { Temp }\end{array}$ & $\begin{array}{c}\text { Desalination } \\
\text { with cooling }\end{array}$ & $\begin{array}{c}\text { Desalination } \\
\text { without } \\
\text { cooling } \\
\mathbf{1 0}\end{array}$ \\
30 & 30 & 90 & $\sqrt{ }$ & $\times$ \\
$\mathbf{1 5}$ & 30 & 30 & 90 & $\sqrt{ }$ & $\times$ \\
$\mathbf{2 0}$ & 30 & 30 & 90 & $\sqrt{ }$ & $\times$ \\
$\mathbf{3 0}$ & 30 & 30 & 90 & $\times$ & $\sqrt{ }$ \\
$\mathbf{2 0}$ & 20 & 30 & 90 & $\times$ & $\sqrt{ }$ \\
$\mathbf{2 0}$ & 30 & 30 & 90 & $\sqrt{ }$ & $\times$ \\
$\mathbf{2 0}$ & 40 & 30 & 90 & $\sqrt{ }$ & $\times$ \\
$\mathbf{2 0}$ & 50 & 30 & 90 & $\sqrt{ }$ & $\times$ \\
\hline
\end{tabular}


As it was highlighted earlier, adsorption systems can be used for water desalination to either produce potable water only or to produce both potable water and cooling effect. Fig. 12 shows the temperature profile of the main adsorption desalination system components. Based on the data extracted from Fig. 6, Fig. 13 shows a. distilled water produced (SDWP), b. cooling effect (SCP) and c. coefficient of performance ( $\left.\mathrm{COP}_{\text {ref }}\right)($ Eq. 7) of aluminium fumarate.

$$
\begin{gathered}
Q_{\text {des }}=\frac{m_{\text {hot }}^{\cdot} C_{p_{w}} \int_{0}^{t_{\text {cycle }}}\left(T_{h o t, \text { in }}-T_{h o t, \text { out }}\right) d t}{t_{\text {cycle }}} \\
\operatorname{COP}_{\text {ref }}=\int_{0}^{t_{\text {cocle }}} \frac{Q_{\text {evap }}}{Q_{\text {des }}} d t
\end{gathered}
$$

It can be noticed that at chilled water inlet temperatures used in cooling $\left(10\right.$ and $\left.15^{\circ} \mathrm{C}\right)$, aluminium fumarate produced SDWP of 2.6 and $4.6 \mathrm{~m}^{3}$ ton $^{-1}$ day ${ }^{-1}$ and a cooling effect of 65 and $136 \mathrm{~W} \mathrm{~kg}^{-1}$, respectively. For a moderate cooling effect $\left(20^{\circ} \mathrm{C}\right)$, aluminium fumarate produced $7 \mathrm{~m}^{3}$ ton $^{-1}$ day $^{-1}$ and $191 \mathrm{~W} \mathrm{~kg}^{-1}$. Regarding the desalination without cooling effect, Fig. 14 shows that at high evaporation temperatures aluminium fumarate produced $13 \mathrm{~m}^{3}$ ton ${ }^{1}$ day $^{-1}$

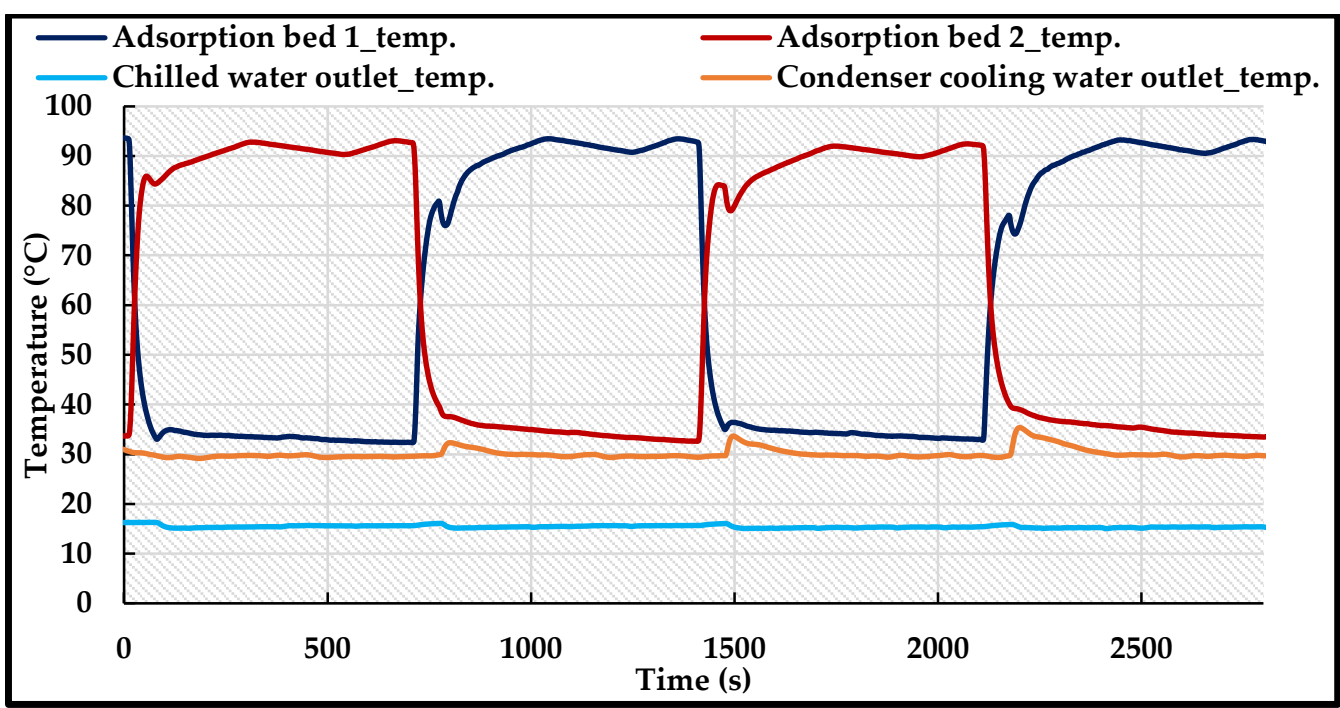

Fig. 12 Temperature profile of adsorption/desorption beds, evaporator and condenser in adsorption desalination system.

$\left(T_{\text {eva }}=15^{\circ} \mathrm{C}, T_{\text {ads }}=30^{\circ} \mathrm{C}\right.$, half cycle time $\left.=700 \mathrm{~s}, t_{\text {switching }}=70 \mathrm{~s}, \mathrm{~T}_{\text {cond }}=30^{\circ} \mathrm{C}, \mathrm{T}_{\text {des }}=90^{\circ} \mathrm{C}\right)$. 

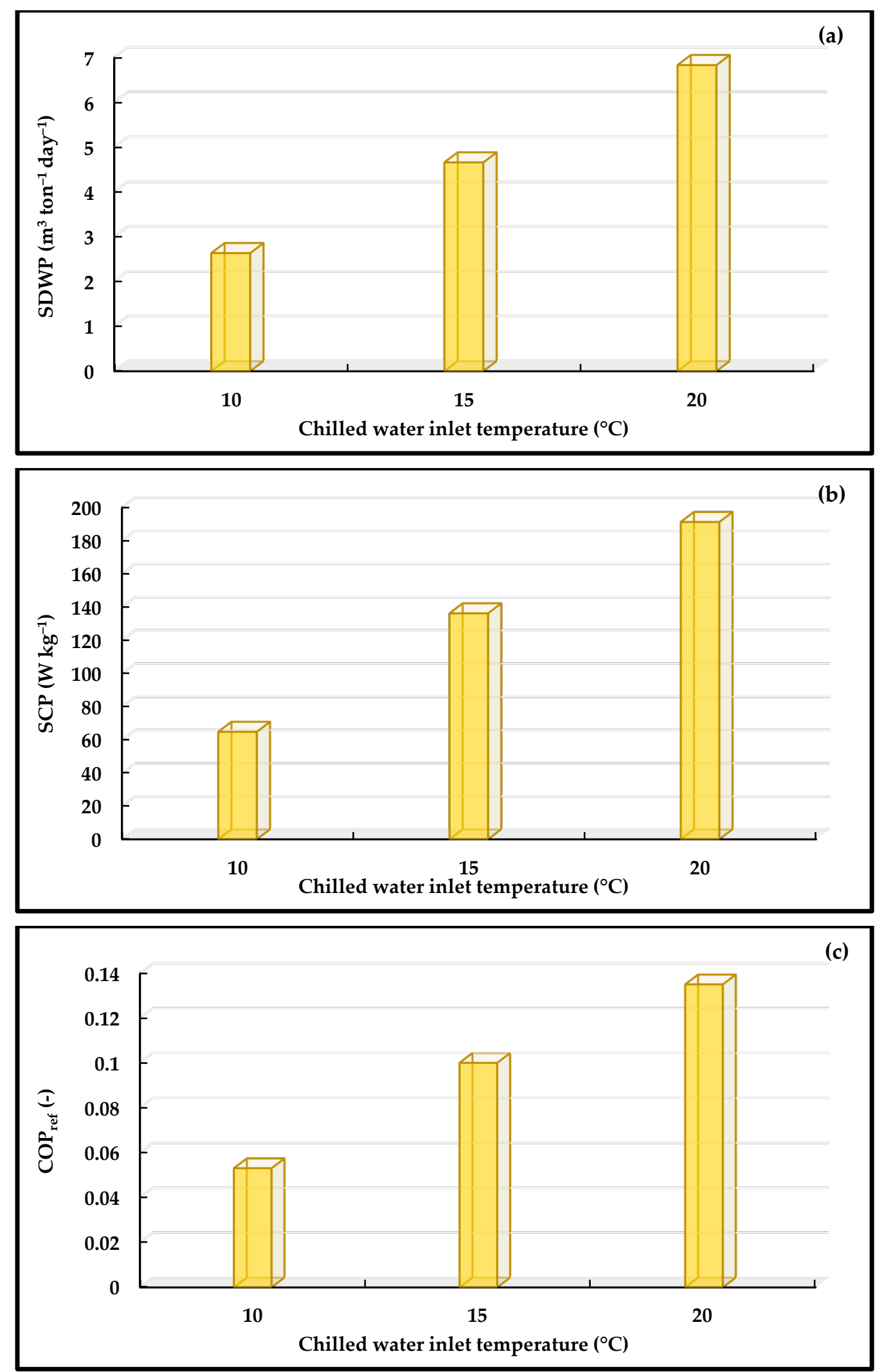

Fig. 13 Adsorption desalination with cooling effect.

a. SDWP, b. SCP and c. COP ref

$\left(T_{\text {ads }}=30^{\circ} \mathrm{C}\right.$, half cycle time $\left.=700 \mathrm{~s}, t_{\text {switching }}=70 \mathrm{~s}, \mathrm{~T}_{\text {cond }}=30^{\circ} \mathrm{C}, \mathrm{T}_{\text {des }}=90^{\circ} \mathrm{C}\right)$. 


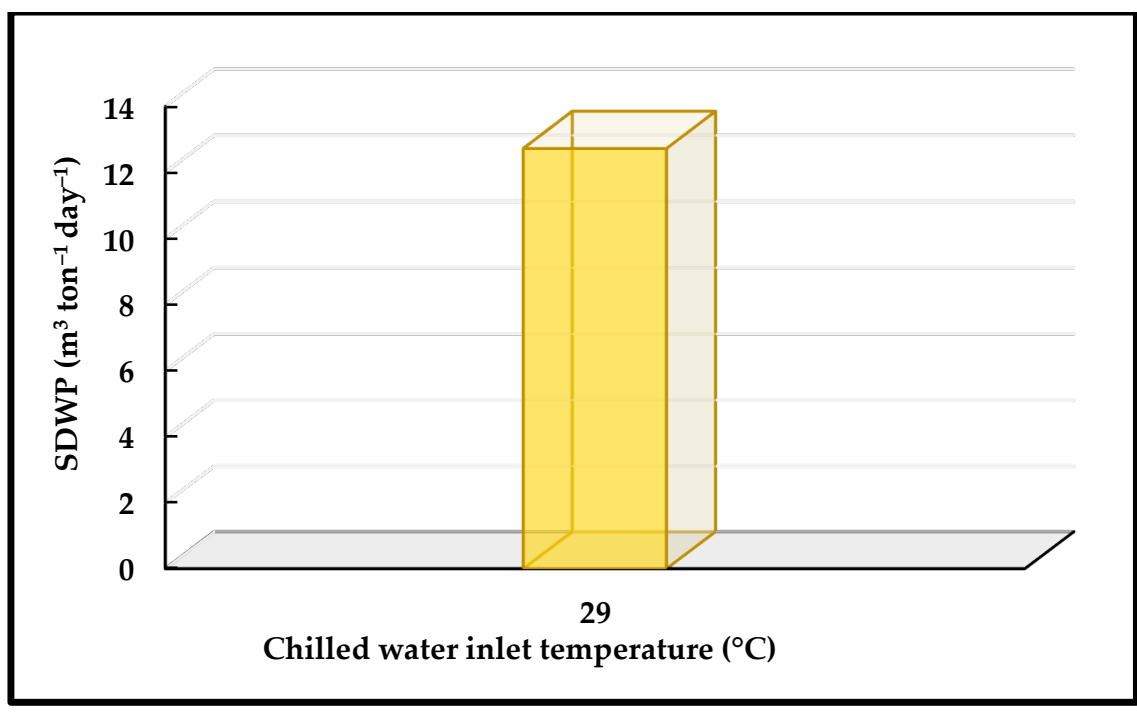

Fig. 14 Adsorption desalination without cooling effect.

$\left(\mathrm{T}_{\text {ads }}=30^{\circ} \mathrm{C}\right.$, half cycle time $\left.=700 \mathrm{~s}, \mathrm{t}_{\text {switching }}=70 \mathrm{~s}, \mathrm{~T}_{\text {cond }}=30^{\circ} \mathrm{C}, \mathrm{T}_{\text {des }}=90^{\circ} \mathrm{C}\right)$.

Salty water was prepared to simulate the seawater. The elemental analysis of the salt used to prepare the salty water can be found in Table 6. The quality of water produced from aluminium fumarate system was assessed through measuring the total dissolved solids (TDS) and water conductivity using a JENWAY $3540 \mathrm{pH}$ and conductivity meter. The measured values were then compared to those of filtered water, tap water and the World Health Organization (WHO) potable water specifications for 2017.

Table 6 Elemental analysis of salt used in preparing salty water:

\begin{tabular}{ll}
\hline Component & Percentage \\
\hline Chloride (Cl) & $38.95 \%$ \\
Sodium (Na) & $12.54 \%$ \\
\hline Magnesium (Mg) & $4.22 \%$ \\
Calcium (Ca) & $1.95 \%$ \\
Sulphur (S) & $0.79 \%$ \\
\hline Potassium (K) & $0.38 \%$ \\
\hline Bromine (Br) & $0.2 \%$ \\
\hline
\end{tabular}


Results in Table 7 shows that the aluminium fumarate desalination system produced high grade distilled water. The TDS decreased from 23,000 ppm for the feed salty water to only $17.5 \mathrm{ppm}$ while the conductivity decreased from $39,000 \mu \mathrm{S} \mathrm{cm}^{-1}$ to $28 \mu \mathrm{S} \mathrm{cm}^{-1}$. According to the WHO standards and based on the measurement shown below, the adsorption system under investigation has proven its ability to be used for distilled water production.

Table 7 Quality analysis of water produced from aluminium fumarate:

\begin{tabular}{lcc}
\hline Sample & TDS $\left(\mathbf{m g ~ L}^{-\mathbf{1}}\right)$ & Conductivity $\left(\boldsymbol{\mu S} \mathbf{~ c m}^{-\mathbf{1}}\right)$ \\
\hline Tap water (UoB) & 94 & 157.1 \\
Filtered water (UoB) & 1.24 & 2.1 \\
Potable water (WHO) $[\mathbf{4 5}, \mathbf{4 6}]$ & $<600$ & 2500 \\
$\begin{array}{l}\text { Feed water to aluminium fumarate } \\
\text { desalination system }\end{array}$ & $23.3 \mathrm{E} 3$ & $39.1 \mathrm{E} 3$ \\
$\begin{array}{l}\text { Water produced from aluminium fumarate } \\
\text { desalination system }\end{array}$ & 17.5 & 28 \\
\hline
\end{tabular}

\subsection{Adsorption desalination: A comparative study:}

The experimental testing results of aluminium fumarate in adsorption desalination application was compared to the experimental results available in the literature as shown in Fig. 15 and Fig. 16. The performance of the adsorbent materials was compared for both with and without cooling effects desalination systems. In Fig.15 and for an ambient temperature of $30^{\circ} \mathrm{C}$ representing the adsorption bed cooling water and to generate a cooling effect, a chilled water inlet temperature of $10^{\circ} \mathrm{C}$ or $15^{\circ} \mathrm{C}$ is usually used. At a chilled water of $10^{\circ} \mathrm{C}$, it was found that silica gel outperformed aluminium fumarate as it produced an SDWP of $3.2 \mathrm{~m}^{-3} \mathrm{ton}^{-1} \mathrm{day}^{-1}$ and an SCP of $70 \mathrm{~W} \mathrm{~kg}$ compared to $2.6 \mathrm{~m}^{-3} \mathrm{ton}^{-1} \mathrm{day}^{-1}$ and $64 \mathrm{~W} \mathrm{~kg}^{-1}$. As the temperature increased to $15^{\circ} \mathrm{C}$, aluminium fumarate surpassed silica gel producing SDWP of 4.6 $\mathrm{m}^{-3} \mathrm{ton}^{-1} \mathrm{day}^{-1}$ and SCP of $136 \mathrm{~W} \mathrm{~kg}^{-1}$ compared to $4 \mathrm{~m}^{-3}$ ton $^{-1}$ day $^{-1}$ and $91 \mathrm{~W} \mathrm{~kg}^{-1}$ in case of silica gel. This is attributed to the increase in the working relative pressure which significantly affects the performance of aluminium fumarate as highlighted earlier. For a moderate cooling in which 
the chilled water inlet temperature of $20^{\circ} \mathrm{C}$ is used, the same performance was observed as aluminium fumarate outperformed the silica gel.

In case of desalination without cooling, the chilled water inlet temperature used is almost equal to the adsorption cooling water temperature. Aluminium fumarate showed a higher SDWP compared to silica gel (Fig. 16) due to the high working relative pressure which is close to unity. The performance of aluminium fumarate was also compared to the performance of another MOF material of CPO-27(Ni) which is known for its good performance at the low relative pressure ranges. It was found that aluminium fumarate surpassed CPO$27(\mathrm{Ni})$ at the investigated temperature range which is attributed to the fact that $\mathrm{CPO}-27(\mathrm{Ni})$ requires high regeneration temperatures to desorb all the adsorbed water. This highlights the advantage of using aluminium fumarate in adsorption system operated by low temperature heat sources as this material can be regenerated using desorption temperatures as low as $60^{\circ} \mathrm{C}$.

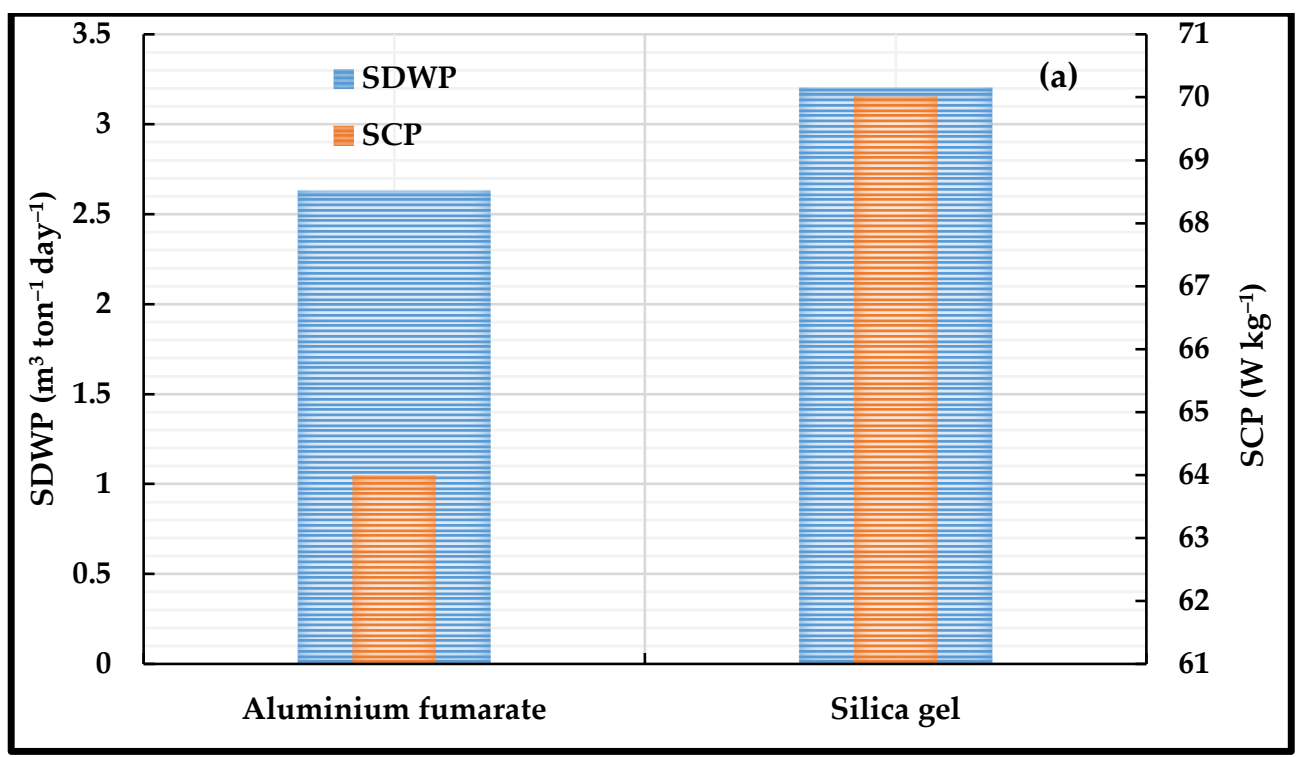



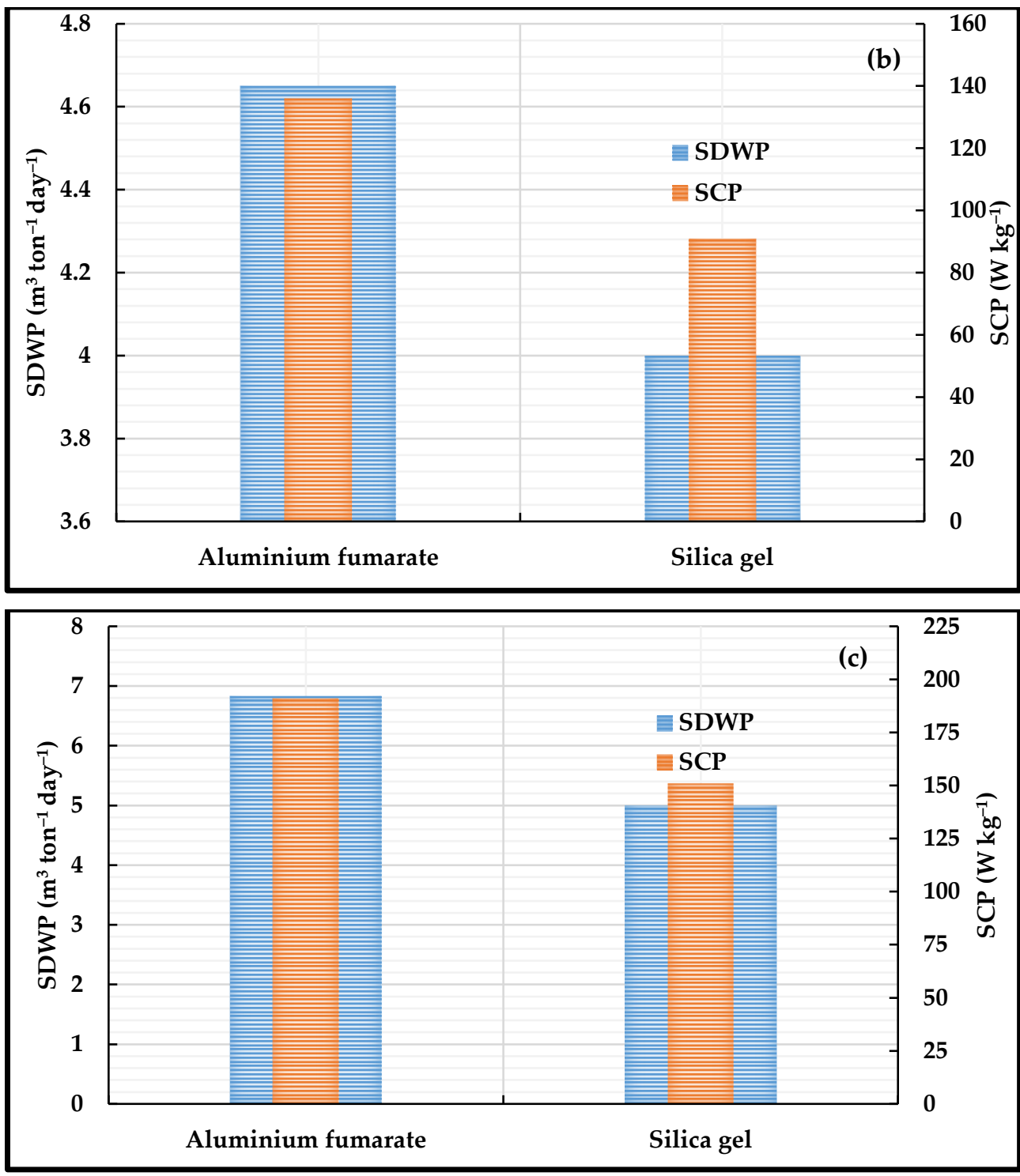

Fig. 15 Adsorption desalination with cooling effect comparative study between silica gel and aluminium fumarate employing a chilled water inlet temperature of a.10 ${ }^{\circ} \mathrm{C}$, b. $15^{\circ} \mathrm{C}$ and c. $20^{\circ} \mathrm{C}[47]$. 

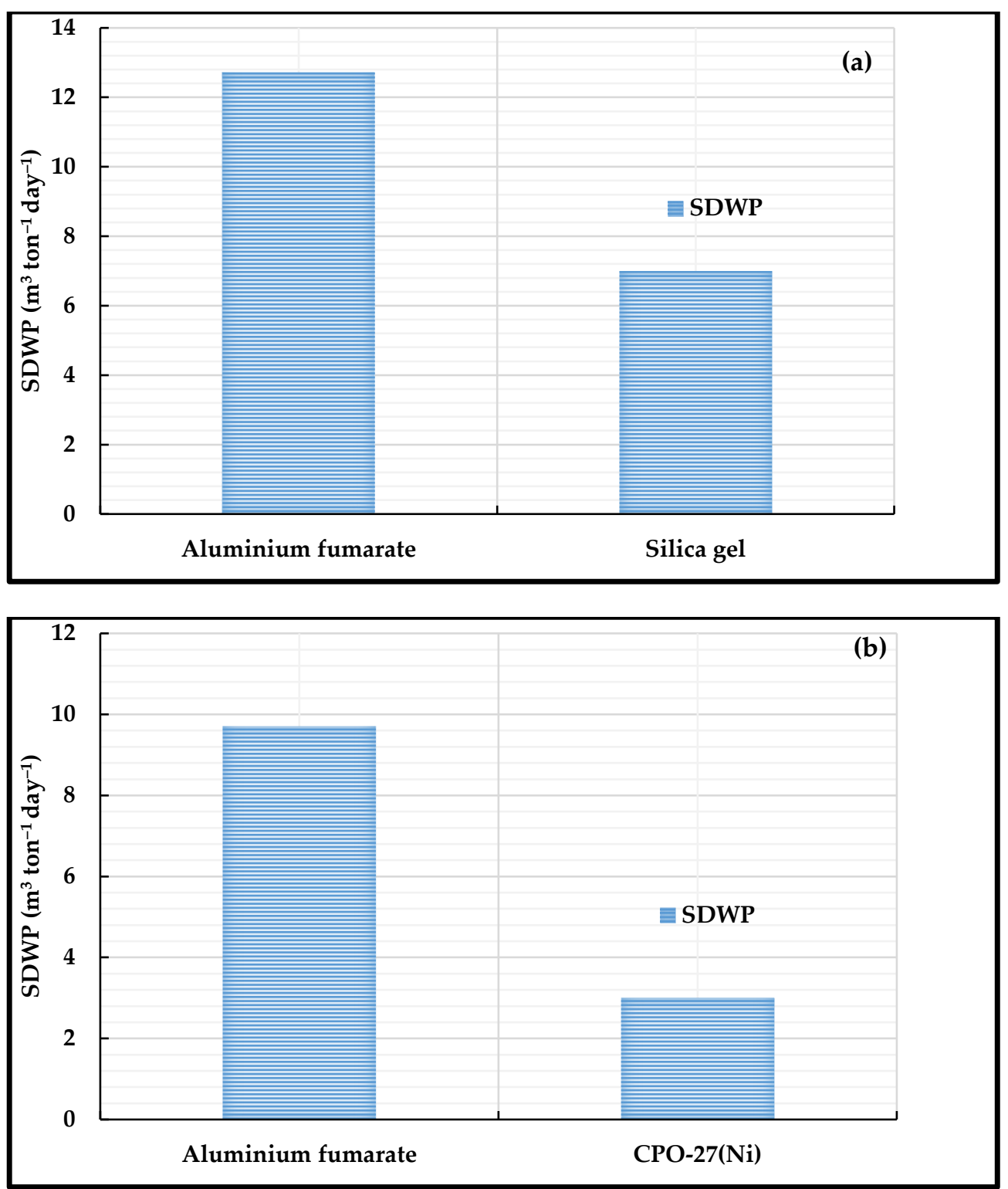

Fig. 16 Adsorption desalination without cooling effect comparative study between aluminium fumarate, a. silica gel [47] and b.CPO-27(Ni) [48]. 


\section{Conclusion:}

The aim of this study was to experimentally assess the potential of aluminium fumarate in adsorption desalination application. A parametric study to experimentally investigate the effect of different parameters such as chilled water, adsorption cooling water, condensation cooling water, desorption heating water temperatures and half cycle time on the performance of the adsorption system was developed. Also, the performance of the aluminium fumarate was also compared to conventional adsorbents such as silica gel and zeolites. Results showed that aluminium fumarate requires a desorption temperature as low as $70^{\circ} \mathrm{C}$ or even less which make the material suitable for applications operated by low temperature heat sources. It was also found that when working at an adsorption temperature of $30^{\circ} \mathrm{C}$, aluminium fumarate surpassed the conventional silica gel at a chilled water temperature higher than $10^{\circ} \mathrm{C}$. This was attributed to the shape of its adsorption isotherm.

This study is a step forward to substitute the long dominating silica gel with a more energy efficient and higher water productive adsorbent material, aluminium fumarate. 


\section{References}

[1] C. Scheele, "Chemische Abhandlung von der Luft und dem Feuer ("Chemical Treatise of Air and Fire"), 1777," Upsala und Leipzig, Verlegt von Magn. Swederus, Buchhändler.

[2] F. Fontana, "Encyclopedia of surface and colloid science," Memorie Mat. Soc. Ital. Sci, vol. 679, 1777.

[3] A. Dąbrowski, "Adsorption-from theory to practice," Advances in colloid and interface science, vol. 93, no. 1, pp. 135-224, 2001.

[4] T. de Saussure, Observations sur l'absorption des gaz par différens corps, 1814.

[5] H. Furukawa, F. Gándara, Y.-B. Zhang, J. Jiang, W. L. Queen, M. R. Hudson, and O. M. Yaghi, "Water adsorption in porous metal-organic frameworks and related materials," Journal of the American Chemical Society, vol. 136, no. 11, pp. 4369-4381, 2014.

[6] M. J. Kalmutzki, C. S. Diercks, and O. M. Yaghi, "Metal-organic frameworks for water harvesting from air," Advanced Materials, vol. 30, no. 37, pp. 1704304, 2018.

[7] H. Kim, S. Yang, S. R. Rao, S. Narayanan, E. A. Kapustin, H. Furukawa, A. S. Umans, O. M. Yaghi, and E. N. Wang, "Water harvesting from air with metal-organic frameworks powered by natural sunlight," Science, vol. 356, no. 6336, pp. 430-434, 2017.

[8] H. Kim, S. R. Rao, E. A. Kapustin, L. Zhao, S. Yang, O. M. Yaghi, and E. N. Wang, "Adsorptionbased atmospheric water harvesting device for arid climates," Nature communications, vol. 9, no. 1, pp. 1191, 2018.

[9] F. Fathieh, M. J. Kalmutzki, E. A. Kapustin, P. J. Waller, J. Yang, and O. M. Yaghi, "Practical water production from desert air," Science advances, vol. 4, no. 6, pp. eaat3198, 2018.

[10] K. Wang, "flsorpiio," 2011.

[11] A. Khutia, H. U. Rammelberg, T. Schmidt, S. Henninger, and C. Janiak, "Water sorption cycle measurements on functionalized MIL-101Cr for heat transformation application," Chemistry of Materials, vol. 25, no. 5, pp. 790-798, 2013.

[12] S. Ülkü, "Adsorption heat pumps," Journal of heat recovery systems, vol. 6, no. 4, pp. 277284, 1986.

[13] P. Aprea, B. de Gennaro, N. Gargiulo, A. Peluso, B. Liguori, F. lucolano, and D. Caputo, "Sr-, $\mathrm{Zn}$-and $\mathrm{Cd}$-exchanged zeolitic materials as water vapor adsorbents for thermal energy storage applications," Applied Thermal Engineering, vol. 106, pp. 1217-1224, 2016.

[14] A. Rezk, R. Al-Dadah, S. Mahmoud, and A. Elsayed, "Effects of contact resistance and metal additives in finned-tube adsorbent beds on the performance of silica gel/water adsorption chiller," Applied Thermal Engineering, vol. 53, no. 2, pp. 278-284, 2013.

[15] A. Rezk, R. Al-Dadah, S. Mahmoud, and A. Elsayed, "Experimental investigation of metal organic frameworks characteristics for water adsorption chillers," Proceedings of the Institution of Mechanical Engineers, Part C: Journal of Mechanical Engineering Science, vol. 227, no. 5, pp. 992-1005, 2013.

[16] B. Shi, "Development of an MOF based adsorption air conditioning system for automotive application," University of Birmingham, 2015.

[17] H. Kummer, G. Füldner, and S. K. Henninger, "Versatile siloxane based adsorbent coatings for fast water adsorption processes in thermally driven chillers and heat pumps," Applied Thermal Engineering, vol. 85, pp. 1-8, 2015.

[18] O. Cheung, and N. Hedin, "Zeolites and related sorbents with narrow pores for $\mathrm{CO} 2$ separation from flue gas," Rsc Advances, vol. 4, no. 28, pp. 14480-14494, 2014.

[19] S. M. Salman, "United Nations General Assembly Resolution: International Decade for Action, Water for Life, 2005-2015: A Water Forum Contribution," Water international, vol. 30, no. 3, pp. 415-418, 2005.

[20] E. Elsayed, A.-D. Raya, S. Mahmoud, P. A. Anderson, A. Elsayed, and P. G. Youssef, "CPO-27 (Ni), aluminium fumarate and MIL-101 (Cr) MOF materials for adsorption water desalination," Desalination, vol. 406, pp. 25-36, 2017. 
[21] T. Mezher, H. Fath, Z. Abbas, and A. Khaled, "Techno-economic assessment and environmental impacts of desalination technologies," Desalination, vol. 266, no. 1, pp. 263273, 2011.

[22] A. Subramani, and J. G. Jacangelo, "Emerging desalination technologies for water treatment: a critical review," Water research, vol. 75, pp. 164-187, 2015.

[23] V. G. Gude, "Desalination and sustainability-an appraisal and current perspective," Water research, vol. 89, pp. 87-106, 2016.

[24] K. C. Ng, K. Thu, Y. Kim, A. Chakraborty, and G. Amy, "Adsorption desalination: an emerging low-cost thermal desalination method," Desalination, vol. 308, pp. 161-179, 2013.

[25] A. S. Alsaman, A. A. Askalany, K. Harby, and M. S. Ahmed, "A state of the art of hybrid adsorption desalination-cooling systems," Renewable and Sustainable Energy Reviews, vol. 58, pp. 692-703, 2016.

[26] K. C. Ng, X. WANG, L. Gao, A. Chakraborty, B. B. Saha, S. Koyama, A. Akisawa, and T. Kashiwagi, "Apparatus and method for desalination," Google Patents, 2006.

[27] Y.-D. Kim, K. Thu, M. E. Masry, and K. C. Ng, "Water quality assessment of solar-assisted adsorption desalination cycle," Desalination, vol. 344, pp. 144-151, 2014.

[28] P. G. Youssef, S. M. Mahmoud, and R. K. Al-Dadah, "Effect of evaporator temperature on the performance of water desalination/refrigeration adsorption system using AQSOA-ZO2," World Academy of Science, Engineering and Technology, International Journal of Environmental, Chemical, Ecological, Geological and Geophysical Engineering, vol. 9, no. 6, pp. 701-705, 2015.

[29] M. W. Shahzad, K. C. Ng, K. Thu, B. B. Saha, and W. G. Chun, "Multi effect desalination and adsorption desalination (MEDAD): A hybrid desalination method," Applied Thermal Engineering, vol. 72, no. 2, pp. 289-297, 2014.

[30] K. C. Ng, K. Thu, A. Chakraborty, B. B. Saha, and W. G. Chun, "Solar-assisted dual-effect adsorption cycle for the production of cooling effect and potable water," International Journal of Low-Carbon Technologies, vol. 4, no. 2, pp. 61-67, 2009.

[31] K. Thu, K. C. Ng, B. B. Saha, A. Chakraborty, and S. Koyama, "Operational strategy of adsorption desalination systems," International Journal of Heat and Mass Transfer, vol. 52, no. 7, pp. 1811-1816, 2009.

[32] K. C. Ng, K. Thu, B. B. Saha, and A. Chakraborty, "Study on a waste heat-driven adsorption cooling cum desalination cycle," International Journal of refrigeration, vol. 35, no. 3, pp. 685693, 2012.

[33] S. Mitra, K. Srinivasan, P. Kumar, S. Murthy, and P. Dutta, "Solar driven adsorption desalination system," Energy Procedia, vol. 49, pp. 2261-2269, 2014.

[34] K. Thu, H. Yanagi, B. B. Saha, and K. C. Ng, "Performance analysis of a low-temperature waste heat-driven adsorption desalination prototype," International Journal of Heat and Mass Transfer, vol. 65, pp. 662-669, 2013.

[35] K. Thu, A. Chakraborty, Y.-D. Kim, A. Myat, B. B. Saha, and K. C. Ng, "Numerical simulation and performance investigation of an advanced adsorption desalination cycle," Desalination, vol. 308, pp. 209-218, 2013.

[36] P. G. Youssef, S. M. Mahmoud, and R. K. Al-Dadah, "Performance analysis of four bed adsorption water desalination/refrigeration system, comparison of AQSOA-ZO2 to silica-gel," Desalination, vol. 375, pp. 100-107, 2015.

[37] E. Elsayed, A.-D. Raya, S. Mahmoud, A. Elsayed, and P. A. Anderson, "Aluminium fumarate and CPO-27 (Ni) MOFs: Characterization and thermodynamic analysis for adsorption heat pump applications," Applied Thermal Engineering, vol. 99, pp. 802-812, 2016.

[38] F. N. Al-Mousawi, R. Al-Dadah, and S. Mahmoud, "Different bed configurations and time ratios: Performance analysis of low-grade heat driven adsorption system for cooling and electricity," Energy conversion and management, vol. 148, pp. 1028-1040, 2017. 
[39] F. N. Al-Mousawi, R. Al-Dadah, and S. Mahmoud, "Low grade heat driven adsorption system for cooling and power generation with small-scale radial inflow turbine," Applied energy, vol. 183, pp. 1302-1316, 2016.

[40] F. Jeremias, D. Fröhlich, C. Janiak, and S. K. Henninger, "Advancement of sorption-based heat transformation by a metal coating of highly-stable, hydrophilic aluminium fumarate MOF," RSC Advances, vol. 4, no. 46, pp. 24073-24082, 2014.

[41] M. Gaab, N. Trukhan, S. Maurer, R. Gummaraju, and U. Müller, "The progression of Al-based metal-organic frameworks-From academic research to industrial production and applications," Microporous and Mesoporous Materials, vol. 157, pp. 131-136, 2012.

[42] E. Alvarez, N. Guillou, C. Martineau, B. Bueken, B. Van de Voorde, C. Le Guillouzer, P. Fabry, F. Nouar, F. Taulelle, and D. De Vos, "The structure of the aluminum fumarate metal-organic framework A520," Angewandte Chemie International Edition, vol. 54, no. 12, pp. 3664-3668, 2015.

[43] N. Tannert, C. Jansen, S. Nießing, and C. J. D. T. Janiak, "Robust synthesis routes and porosity of the Al-based metal-organic frameworks Al-fumarate, CAU-10-H and MIL-160," vol. 48, no. 9, pp. 2967-2976, 2019.

[44] H. Kummer, F. Jeremias, A. Warlo, G. Füldner, D. Fröhlich, C. Janiak, R. Gläser, S. K. J. I. Henninger, and E. C. Research, "A functional full-scale heat exchanger coated with aluminum fumarate metal-organic framework for adsorption heat transformation," vol. 56, no. 29, pp. 8393-8398, 2017.

[45] F. Edition, "Guidelines for drinking-water quality," WHO chronicle, vol. 38, no. 4, pp. 104-8, 2011.

[46] W. H. Organization, "Guidelines for drinking-water quality: first addendum to the fourth edition," 2017.

[47] K. Thu, "Adsorption desalination: theory \& experiments," 2010.

[48] P. G. Youssef, H. Dakkama, S. M. Mahmoud, and R. K. J. D. AL-Dadah, "Experimental investigation of adsorption water desalination/cooling system using CPO-27Ni MOF," vol. 404, pp. 192-199, 2017. 